\title{
Mito y tragedia griega en la literatura iberoamericana ${ }^{1}$
}

\author{
Pilar Hualde Pascual \\ Universidad Autónoma de Madrid \\ pilar.hualde@uam.es
}

Recibido: 12-6-2011

Aceptado: 30-12-2011

\section{RESUMEN}

En este trabajo pretendemos hacer un catálogo razonado de las obras de la literatura iberoamericana de los siglos XX y XXI que han continuado explícitamente los principales temas de la tragedia griega, clasificándolas según los mitos que desarrollan, con el fin de ver la diversidad funcional que éstos representan en las distintas circunstancias en que se produce la obra receptora.

Palabras clave: Tragedia griega, literatura iberoamericana, tradición clásica.

\begin{abstract}
In this paper, we make a catalog of the works of Latin American literature of Xx and XxI centuries that have dealt with the major themes of Greek tragedy. Also we will classify as myths developed to see the diversity of functions depending on the circumstances in which the modern work place.
\end{abstract}

Key words: Greek Tragedy, Iberoamerican Literature, Classical Tradition.

SUMARIO: 1. Introducción. Justificación del tema. 2. Precedentes. La tragedia griega en la Iberoamérica de la conquista y de la época colonial. Temas de la tragedia griega en la escena iberoamericana del siglo xIx. 3. La recuperación de la tragedia griega en Iberoamérica: Las primeras traducciones y los primeros estudios sobre el drama ático. 4. El siglo xx: La tragedia griega evocada o recreada. La tragedia como vehículo de comunicación ideológico en Iberoamérica. 4.1. El Prometeo. 4.2. La saga de Atreo 4.2.1. Las Ifigenias. 4.2.2. Las Electras, Clitemnestras y Orestes. 4.3. La saga tebana. 4.3.1. El Edipo Rey. 4.3.2. Las Antígonas. 4.3.3. Los Siete contra Tebas. 4.4. Las Medeas. 4.5. Otros mitos euripideos revisitados por la literatura iberoamericana. 5. A modo de conclusión.

\footnotetext{
${ }^{1}$ Una primera versión de este trabajo se presentó como ponencia al I Encuentro Internacional sobre Traducción y Tradición de autores griegos y latinos en América Latina, celebrado en la Universidad Autónoma de Madrid entre el 11 y 14 de enero de 2011, en el marco del proyecto CEAL-Banco de Santander coordinado por la Profesora Helena Maquieira (UAM).
} 


\section{INTRODUCCIÓN. JUSTIFICACIÓN DEL TEMA}

Parece conveniente en el comienzo de este trabajo justificar un título que da cuenta de una pretensión tan inabarcable como sintetizar en el estrecho margen de unas páginas todo lo que ha significado la tragedia griega en el contexto iberoamericano. Hemos de decir que nuestra incursión en este tema, que se revela apasionante, tiene su punto de partida en el encargo que se nos realiza en la primavera de 2010 de hacer la entrada Greek Tragedy in Latin America Literature para la Encyclopedia of Greek Tragedy, que se publicará próximamente en la editorial Wiley-Blackwell. Este encargo pretendía la obtención de una panorámica general de la impronta de la tragedia griega en el subcontinente americano, que abarcara aspectos tan diversos como la traducción, la influencia, la adaptación y la recepción. Así, la primera parte del trabajo consistió en localizar y reseñar las más tempranas traducciones de tragedia griega llevadas a cabo por autores iberoamericanos, intentando justificar el porqué de su fecha de aparición en función de los cánones estéticos de la América del momento y, a partir de ahí, nos internamos en la influencia que han tenido los trágicos atenienses en la obra de creación de los grandes escritores de Latinoamérica. Dada la ingente cantidad de material reunido y las complejas relaciones entre mito, drama antiguo, país, situación sociopolítica y obra literaria moderna, encontramos aconsejable ampliar nuestro trabajo de forma que, aun sin ninguna pretensión de exhaustividad, pudiéramos hacer una primera aproximación general al significado de la tragedia griega en la literatura iberoamericana actual.

No es, desde luego, fácil dar una visión de conjunto de la multitud de obras de autores latinoamericanos bajo las que late, en distinto grado, el texto y el espíritu del antiguo drama ático. En primer lugar, el acceso a algunos de los textos dramáticos americanos (especialmente a los más recientes) es un hecho prácticamente imposible. Por otra parte, hay diversos niveles de transparencia en la reutilización del mito, y resulta mucho más sencillo identificar aquellas obras que desde el propio título continúan el del drama clásico (caso de las abundantes Antígonas, Medeas o Electras americanas), que aquellas en las que los personajes del mito aparecen reescritos de forma menos obvia.

Dadas las circunstancias, podemos cuestionarnos la manera de organizar un material tan abundante y complejo. Cabría la posibilidad de utilizar distintos criterios organizativos en nuestra revisión del tema: agrupar las obras por países, considerarlas en función del género literario de la obra de llegada, o por el contenido ya político, ya social, ya psicológico del texto. Sin embargo, nos ha parecido más productivo organizar nuestro corpus por los mitos o sagas míticas que utilizaron los trágicos atenienses, sin perjuicio de que, dentro de ellos, se haga referencia al tipo de utilización que del antiguo mito hace el autor moderno. A la elaboración de este catálogo añadimos una revisión bibliográfica del tema lo más exhaustiva posible, que presentamos en las correspondientes notas a pie de página. Este no es un asunto baladí, ya que el tema aquí tratado se ha abordado en numerosísimas ocasiones, pero de forma atomizada, bien en función de la presencia un determinado mito $^{2}$, bien en función de la nación

${ }^{2}$ Es notable la recopilación de artículos sobre el mito de Medea en el teatro actual en los distintos volúmenes coordinados por LóPEZ, Aurora y PociÑA, Andrés (2002) y (2007). Asimismo, sobre el mito de Fedra cf. LóPeZ, Aurora y PociÑA, Andrés (2008). 
receptora del mismo, y de forma independiente desde los estudios de Filología Española, de Filología Clásica ${ }^{3}$, o directamente a partir de los estudios escénicos, sin que, habitualmente, se pongan en común los aspectos analizados desde cada ámbito del conocimiento. Con estos presupuestos, pues, hemos procedido en nuestro trabajo mediante un orden derivado de la obra de partida, es decir, repasaremos la influencia de cada obra de los trágicos en la literatura de cada uno de los países latinoamericanos, estructurándolo a partir de las sagas míticas que sustentan cada drama, teniendo en cuenta, en la medida de lo posible, la relación hipotextual (inspiración temática) e intertextual (presencia del texto clásico en la obra moderna), sin olvidar los aspectos architextuales o de relación genérica, ya que en ocasiones reseñaremos la presencia de la tragedia griega no sólo en textos dramáticos iberoamericanos, sino también en otros géneros literarios distintos.

\section{PRECEDENTES. LA TRAGEDIA GRIEGA EN LA IBEROAMÉRICA DE LA CONQUISTA Y DE LA ÉPOCA COLONIAL. TEMAS DE LA TRAGEDIA GRIEGA EN LA ESCENA IBEROAMERICANA DEL SIGLO XIX}

Siendo como es la tragedia el género literario griego que más repercusión ha tenido en el mundo iberoamericano de los siglos Xx y XXI, es llamativo observar cómo en tiempos de la conquista y la colonia el drama ateniense está ausente del espacio literario americano. En estos momentos, la transmisión de la cultura clásica está ligada estrechamente a la educación que se halla en manos del Estado y de la Iglesia, especialmente de algunas órdenes religiosas como los jesuitas, y los géneros literarios productivos en esta educación son la retórica y la filosofía. Por lo demás, priman con mucho los autores latinos sobre los griegos, que en este momento son una mera referencia conocida a través de la literatura latina, siendo los autores clásicos que triunfan en el canon del momento Ovidio, Virgilio o Cicerón. En los comienzos del siglo XIX, mientras se gestan los distintos movimientos de liberación americanos, siguen siendo los autores latinos los que suponen el sustento clásico en las diversas revoluciones, sobre todo los retóricos, maestros del arte de hablar tan necesario para la actividad política.

En cuanto a los conocimientos de lenguas clásicas, a partir del siglo XIX decae la enseñanza de las lenguas muertas, cuyo cultivo queda casi exclusivamente reducido al ámbito de la educación en centros religiosos, en los que se enseña especialmente el latín y, en mucho menor grado, el griego ${ }^{4}$.

Sin embargo, es reseñable cómo en la segunda mitad del XIX aparecen algunas personalidades intelectuales de sólida formación clásica y conocimientos notables de la lengua latina y, en ocasiones, también de la griega, en los distintos países de Latinoamérica, hecho que se deben a su formación europea o a la presencia de preceptores eu-

\footnotetext{
${ }^{3}$ Son destacables los numerosos volúmenes sobre la pervivencia del mito en el teatro actual, de Morenilla, Carmen, De Martino, Francesco, Bañuls, J. V. (2001, 2006), o De Martino, Francesco, MoreNILLA, Carmen (2004).

${ }^{4}$ GonzÁlez de TobíA, Ana M. ${ }^{\mathrm{a}}$ (2004): 87-124 y versión digital (2005).
} 
ropeos en su educación: Andrés Bello, Miguel Antonio Caro o José Martí son algunos de estos intelectuales. Pese a la evidente erudición de estos y algunos otros notables, son muy escasos los individuos que en la segunda mitad del XIX pudieron tener acceso a originales de textos griegos y, desde luego, no tenemos constancia positiva de que se dedicaran a la lectura o estudio del drama ático.

Sin embargo, el género dramático en la Iberoamérica de finales del XVIII y del XIX es de fundamental importancia, tanto en calidad de vehículo educativo, como en calidad de instrumento político, amén de dar cuenta de una característica definitoria de la personalidad iberoamericana.

Durante la primera mitad del siglo XIX son numerosísimas las tragedias que se escriben en el ámbito hispanoamericano $\mathrm{y}$, aunque es cierto que en ellas prima el tema local indigenista, algo esperable en un marco histórico de gestación de nacionalismos, sin embargo, destacan puntualmente algunas tragedias de tema clásico griego y romano. Así, por ejemplo, Domingo Navas Spínola escribe una tragedia de ambientación latina, Virginia (1824), a la par que traduce la Ifigenia en Áulide de Racine; Juan Cruz Varela escribe una Dido ${ }^{5}$, una Argia y un Idomeneo entre 1823 y 1825; José María Salazar tiene un Sacrificio de Idomeneo (1803) ${ }^{6}$ y José María de Heredia escribe un Atreo, imitado del francés, que se representó en Matanzas en 1822.

De ellas, por su temática mitológica, rozarían la tragedia griega la Argia de Cruz Varela, que nos remite al ciclo tebano y el Atreo de Heredia, que nos enlazaría con los antecedentes de la Orestea esquilea. Sin embargo, la Argia de Cruz Varela, buen conocedor de los clásicos latinos, pero cuya lectura de los griegos no nos consta ${ }^{7}$, está creada siguiendo el modelo prerromántico del italiano Vittorio Alfieri, si bien supone un precedente en la actitud que tendrán numerosos dramaturgos del siglo xx al escoger un tema clásico para denunciar desde la escena al tirano, en este caso, la monarquía española que se opone al establecimientos de las nuevas repúblicas americanas independientes. En el caso del Atreo de Heredia, nos encontramos con una obra en cinco actos, de corte neoclásico, adaptación o traducción del francés Crebillón, pero no creada por influencia del drama griego ${ }^{8}$. De inspiración clásica es el drama histórico brasileño Clitemnestra, rainha de Micenas, escrito por Joaquim Norberto da Silva en $1846^{9}$.

En general, puede decirse que durante todo el siglo XIX los temas tocados por la tragedia ática llegan a Iberoamérica a través de recreaciones europeas, francesas e italianas fundamentalmente, $\mathrm{o}$, en el mejor de los casos, a través de traducciones francesas y españolas ${ }^{10}$.

\footnotetext{
${ }^{5}$ Cf. Bernal Lavesa, Carmen (2006):83-112.
}

${ }^{6}$ Cf. el completísimo trabajo de vilanova, Ángel (2006); asimismo fundamental para el conocimiento del tema es Vilanova, Ángel (1998-1999).

7 VILANOVA, Ángel (1999), «Las heroínas del drama clásico grecolatino en el teatro iberoamericano: algunas reflexiones sobre la tragedia Argia, de Juan Cruz Varela», en Bañuls Oller, J. V., Sánchez Méndez, J. y Sanmartin Sáez, J. (eds.), Literatura iberoamericana y tradición clásica. Valencia, Universitat Autonoma de Barcelona.

${ }^{8}$ ARENCIBIA RODRÍGUEZ, Lourdes (1993): 1-17.

${ }^{9}$ ALMEIDA CARDOSO, Zelia de (1998-1999): 15-27.

${ }^{10}$ Juan García del Río publicó en el tomo II de La biblioteca Americana un «Catálogo de los autores griegos y romanos de que se hen publicado traducciones en castellano desde el siglo XIV hasta el 
Bello, máximo exponente del estudioso de la Antigüedad en la Iberoamérica de la época y buen representante de los valores estéticos del momento, tiene una opinión significativa sobre el drama griego, ya que el venezolano estimó el teatro del neoclasicismo francés muy por encima de la tragedia ática, de lo que pueden dar buena cuenta las siguientes palabras: «Comparado el teatro griego con el de los franceses, nos parece que sólo una ciega admiración a la antigüedad puede disputar al segundo la gloria de haber perfeccionado bajo algunos respectos el arte».

\section{LA RECUPERACIÓN DE LA TRAGEDIA GRIEGA EN IBEROAMÉRICA: LAS PRIMERAS TRADUCCIONES Y LOS PRIMEROS ESTUDIOS SOBRE EL DRAMA ÁTICO}

Sin embargo, en los últimos años del siglo XIX ya hay constancia en Iberoamérica de un interés filológico que hace que se empiecen a volver los ojos a los textos griegos. Por lo que se refiere al drama ático, la primera traducción de que tengo noticia se llevó a cabo en Chile, por obra del jesuita Juan R. Salas, quien traduce a Esquilo en verso castellano, ilustrando la versión con notas filológicas y críticas. La publicación se llevó a cabo en primer lugar en la Revista de Artes y Letras, en 1889, y luego apareció de forma completa en 1904, en la editorial de la Universidad de Chile. La traducción gozó de las encendidas alabanzas de los eruditos del momento, especialmente de Menéndez Pelayo, que consideró la versión del Prometeo de Salas como obra maestra ${ }^{11}$.

Pero si hay un momento y un lugar desde los que se reivindica el valor de la tragedia griega ese es el México de $1908^{12}$. En la noche del 25 de diciembre de ese año se dan cita en la casa del abogado Agustín Reyes un grupo de jóvenes iberoamericanos con inquietudes intelectuales, entre los que se encontraba el dominicano Pedro Henríquez Ureña y el mexicano Alfonso Reyes. Estos jóvenes eruditos pretendían celebrar «el nacimiento de Dióniso» coincidiendo con el solsticio de invierno, posiblemente influidos por el gusto por lo dionisiaco que había puesto de moda el decadentismo europeo de finales de siglo. En la reunión, Henríquez Ureña leyó su texto dramático en prosa «El nacimiento de Dioniso», más influido por los autores que habían tratado el mito en el XIX, que por las versiones griegas del mismo, pero en el que se deja ver la validez de la tragedia como medio de expresión de la decadencia del hombre en las sociedades modernas y, a su vez, la interpretación de Dióniso como divinidad catárti$\mathrm{ca}^{13}$. Tras el brindis, Alfonso Reyes leyó su poema «Coro de faunos del bosque». Esta reunión, aparentemente anecdótica, fue en buena medida fundacional de una corriente intelectual del México de la época, aglutinada en torno al llamado Ateneo de la Juventud, con la presencia de estas dos figuras señeras para las que la tragedia griega tendrá un especial peso, como podremos posteriormente observar en la obra de creación de

precedente, por Don Antonio Campmany", en el que se consignaba el Aristófanes, Terencio y Eurípides traducidos por Pedro Simón Abril.

${ }^{11}$ Henríquez Ureña, Pedro (2008).

${ }^{12}$ Quintanilla, Susana (2002): 619-663.

${ }^{13}$ Quintanilla, Susana (2002). 
Alfonso Reyes. Éste, que había hecho sus primeras lecturas del drama ático en la versión inglesa de Gilbert Murray y que, precisamente en el mismo año 1908, se verá muy influido por la lectura nieztchiana de El origen de la Tragedia, escribió, asimismo en estas fechas, su ensayo «Las tres Electras del teatro ateniense». Reyes considerará la tragedia como el género que aúna el elemento dramático (representado por el héroe en los episodios), la narrativa (representada por las escenas de mensajero) y el elemento poético, representado por el coro que sirve de válvula emocional a la obra ${ }^{14}$.

Sin embargo, terminaba la primera década del nuevo siglo sin otras traducciones de los trágicos en Iberoamérica más que las realizadas por el jesuita Salas a comienzo del siglo. Ya en los años veinte encontramos en Bolivia la conocida versión del Edipo Rey de Sófocles que llevó a cabo el poeta modernista Gregorio Reynolds en 1924. Esta versión poética fue estrenada con cierta polémica por el Círculo de Bellas Artes de La Paz en el mismo año 1924. El poeta, que avisa honestamente en el prólogo de que la traducción está hecha a la vista de las francesas de Lenconte de Lisle y de Paul Masqueray, versifica los diálogos en alejandrinos pareados o endecasílabos asonantados y las partes líricas en distinto tipo de metros, pero es un buen exponente del gusto del modernismo americano por el mundo griego.

En Argentina, en los años veinte, destaca en la traducción de textos de tragedia Leopoldo Longhi de Bracaglia. En este caso, nos encontramos ya con la figura del traductor profesor universitario, pues Longhi, profesor de literatura griega y latina de la Universidad de la Plata, traduce varias tragedias de Eurípides, adaptando algunas de ellas para su representación operística o escénica. Entre estas están Las Bacantes. Reconstrucción escénica y traducción, de 1924 o Fedra, creada sobre el texto de Eurípides y estrenada el 26 de Septiembre de 1925. Tiene además una edición bilingüe de la Hécuba, con versión poética y estudio crítico, Buenos Aires, 1920; y otra versión poética de Medea, publicada en 1922. De Sófocles llevó a cabo una Reconstrucción y versión poética del Edipo Rey, La Plata 1926 y una Antígona que se estrenó el 29 de octubre de 1930.

También dentro del ámbito argentino es preciso mencionar el impagable estudio que años después llevó a cabo M. ${ }^{a}$ Rosa Lida de Malkiel, Introducción al Teatro de Sófocles, publicado en 1944.

Ya en los años cincuenta destacan algunas traducciones de tragedia en el ámbito latinoamericano, con figuras como las de Julián Motta de Salas en Colombia o Aurelio Espinosa Polit en Ecuador ${ }^{15}$. Motta de Salas (1891-1972), conocido cervantista, traductor y diplomático, tradujo Las siete tragedias de Sófocles, publicadas en Bogotá, en 1958. Espinosa Polit (1894-1961), ensayista, poeta, crítico literario, traductor y catedrático universitario, perteneciente a la orden jesuita, que se había formado en su juventud en distintos lugares de Europa (Francia, Suiza, Bélgica e Inglaterra) y hecho sus estudios universitarios de Filosofía y Letras y Teología en España, en Granada y Sarriá, y cursado Estudios Clásicos en Cambridge, cuya docencia impartirá, ya convertido en sacerdote jesuita a su regreso al Ecuador, tradujo de Sófocles el Edipo Rey en verso castellano (1935), el Edipo en Colono, 1936; la Antígona, 1955, y, finalmente, vio

\footnotetext{
${ }^{14}$ ReYes, Alfonso (1981): 452-453.

${ }^{15}$ LAFARGA, Francisco, PEGENAUTE, Luis (2009), s.v. Sófocles.
} 
la luz su traducción completa El teatro de Sófocles en verso castellano, 1959. A partir de los años sesenta, con el desarrollo de los estudios de Filología Clásica en las diversas universidades iberoamericanas, se ha ido dotando poco a poco de traducciones patrias de tragedia griega a los distintos países del subcontinente.

\section{EL SIGLO XX: LA TRAGEDIA GRIEGA EVOCADA O RECREADA. LA TRAGEDIA COMO VEHÍCULO DE COMUNICACIÓN IDEOLÓGICO EN IBEROAMÉRICA}

Es el siglo xx el momento de la gran aparición de la tragedia griega en Iberoamérica, desde el momento en que la obra de los tragediógrafos atenienses se convierte en un vehículo para comunicar las ideas que propugnan los autores americanos, ya en el ámbito político, ya en el social o, incluso, desde un punto de vista psicológico. El peso moral y estético del drama griego se deja ver, tanto por el interés de poner en escena distintas obras de Esquilo, Sófocles y Eurípides ${ }^{16}$, como por el afán de recreación de los argumentos míticos de los trágicos en la literatura iberoamericana del momento. Este resurgir de la tragedia griega en la América de habla hispana, aunque se puede observar ya en las primeras décadas del siglo, tiene su auténtica eclosión a partir de la mitad de la centuria, coincidiendo con la toma de conciencia de las difíciles situaciones políticas de los diversos países. Es interesante, pues, ver qué mitos son los más utilizados en cada lugar y circunstancia. Con este fin, revisaremos las más relevantes versiones americanas del mito de Prometeo, que evocan la obra de Esquilo del mismo nombre; dentro del mito correspondiente a la saga de la casa de Atreo revisaremos las Ifigenias y las Electras americanas, recreadas sobre Ifigenia en Áulide e Ifigenia en Táuride, de Euripides, y sobre Electra de Sófocles y Eurípides, amén de las Coéforas, de Esquilo; en la saga tebana veremos las relecturas del Edipo Rey y de la Antígona de Sófocles, seguidas de Los Siete contra Tebas esquileo, y, a continuación, nos ocuparemos de las numerosas Medeas latinoamericanas, que parten de la tragedia homónima de Eurípides. El trabajo finalizará con la revisión de algunas obras que retoman otros mitos desarrollados en la dramaturgia de Eurípides.

\subsection{El Prometeo}

Sin ser el Prometeo de Esquilo una obra que por sus características haya sido muy recreada con posterioridad a su enorme popularidad en el romanticismo europeo, lo cierto es que es la base de alguna de las más tempranas obras iberoamericanas que hunden sus raíces en el rico terreno de la tragedia griega.

Fuera del architexto dramático, pero dentro del ámbito de la poesía, ya había desarrollado el tema de Prometeo el cubano Julián del Casal, en su poema Las Oceánidas

${ }^{16}$ El interés de los estudiantes de la Universidad de La Habana y de la Academia de Artes Dramáticas en la representación de los clásicos en la Cuba de los años cuarenta ha sido estudiada por MiRANDA CANCELA, Elina (2006). 
(1880) y en el llamado propiamente Prometeo (1881), con tratamientos distintos del mito, en los que se deja ver sus lecturas de Esquilo y de los poetas románticos. ${ }^{17}$

Dentro de los textos dramáticos cabe destacar la Prometheida, tragedia lírica de más de cuatro mil versos, del boliviano Franz Tamayo, publicada en 1917. Franz Tamayo (1879-1956) fue un poeta de corte modernista, que recibió una gran impronta de la literatura griega, adquirida durante sus años de formación en el campo de las humanidades, lo que se deja ver en buena parte de su obra, que, no obstante su influencia helénica, se centra en exaltar la naturaleza del Altiplano. La Prometheida tiene como peculiaridad, frente a la obra de Esquilo, que Prometeo está ausente de la escena y es Psique enamorada quien, rodeada del coro de las Oceánides, busca al filantrópico titán. Ares, Apolo y Atenea, presentan sus respectivos monólogos en respuesta a la búsqueda de ayuda de Psique, pero parece imposible encontrar al titán redentor desaparecido. Atenea revela a Psique que Prometeo está más allá de la muerte y, en ese momento, el Alma enamorada comprende que debe sacrificar su vida para unirse a su amado. Los dioses acuden a ver su sacrificio, y, en el momento supremo de la muerte, surge el canto de Melifrón, el ruiseñor invisible. Todo ello está expuesto con un lenguaje rico y barroco y una inusitada musicalidad modernista. La obra, de carácter marcadamente críptico, ha sido interpretada como una alegoría de la búsqueda del progreso por parte de la Bolivia natal del autor, quien, al regresar a su patria tras sus años europeos, añora desde el mundo americano la luz de los clásicos griegos ${ }^{18}$.

El mexicano José Vasconcelos, compañero de Alfonso Reyes y de Pedro Henríquez Ureña en la recuperación de los clásicos griegos en el seno del Ateneo de la Juventud, escribe el poema dramático Prometeo vencedor. Tragedia moderna en un prólogo y tres actos (1920), texto con importante carga filosófica nitzcheana. La obra, cuyo escaso éxito reconocía implícitamente su autor ${ }^{19}$, es una meditación filosófica, con el ingrediente formal de la presencia del baile del coro - danzas tradicionales mexicanas, con lo que Vasconcelos se adelanta notablemente a la muy frecuente «indigenización» de los cantos corales en la segunda mitad del siglo xx-, símbolo del elemento dionisiaco, y en cuyo texto se pregunta sobre la dicotomía entre las leyes de la naturaleza y del espíritu, sobre la tiranía, sobre la inmortalidad y, con la presencia del elemento autobiográfico tan característico del autor, sobre la soledad de los reformadores. Vasconcelos, que repudia el teatro comercial, busca en la tragedia clásica, la inspiración para crear un espectáculo trascendente, y así, en un primer acto que presenta la lucha de Prometeo, que persigue la implantación de imperio de la voluntad, con Satán (símbolo, entre otras cosas, de la negación del progreso), se preconiza la forja de una nueva humanidad a partir de la América hispana. ${ }^{20}$ La esperanza de esta nueva humanidad, que es indisociable de la situación de descomposición moral subsiguiente a la Primera Guerra Mundial, es llevada por Vasconcelos a la escena en un intento de crear un auténtico teatro nacional, comprometido y trascendente.

\footnotetext{
${ }^{17}$ Miranda Cancela, Elina (1983):15-28.

${ }^{18}$ García Gual, Carlos (2003): 147-168. Cf. también Baptista Gumucio, Mariano (1979).

${ }^{19}$ FeLL, Claude (1994): 549-562.

${ }^{20}$ FelL, Claude (1989): 464-465.
} 
Curiosamente, la segunda mitad del siglo xx, justo en el momento en que el teatro iberoamericano se vuelca en la utilización de los temas de la tragedia griega, parece marginar el mito de Prometeo, con excepciones como la obra con la que se inicia en la dramaturgia el dominicano Héctor Incháustegui Cabral en 1964, Prometeo, considerado como la primera tragedia dominicana ${ }^{21}$.

Muy recientemente se ha vuelto los ojos a la figura del titán filántropo en Prometeo. Hasta el cuello (2008), del argentino Juan José Santillán, para trasladar el mito al contexto de la denuncia de la violencia de la dictadura de los años setenta. Aquí Prometeo ya no sirve para ilustrar un deseo de progreso, sino para hacer un alegato contra la tiranía, en el contexto de una disputa entre dos dirigentes de un partido político, el peronista, denunciado por sus extremos por al autor del texto. Así el protagonista Pontani-Prometeo, es encarcelado por sus compañeros de partido político por haber filtrado un secreto del dirigente Solano-Zeus. Rodríguez y González (Bía y Hefesto) lo encierran en un cuartito, trasunto de la roca del Cáucaso y símbolo del opresivo ambiente nacional, por el que aparecen distintos personajes que van representando las distintas actitudes asumibles ante la situación política: Silvina-las Oceánides, que le incita a la rebelión, Eugenia-Io, la exiliada, Basualdo-Océano, el oportunista político... El simbolismo del agua, que se filtra en la habitación que aparece en escena y que termina empapando a los personajes, hace referencia al diluvio que sufrieron los descendientes del titán, Deucalión y Pirra (aunque no creo que aquí pueda excluirse el recuerdo de Tántalo) y en el texto representa el castigo ante la rebeldía.

\subsection{La saga de Atreo}

\subsubsection{Las Ifigenias}

Tal vez no son las dos tragedias que llevan el nombre de la hija sacrificada de Agamenón las más populares, ni las que más representaciones han tenido en el siglo XX. Sin embargo, no podemos dejar de traerlas a colación, porque dos autores iberoamericanos las tomaron como hipotexto para su obra en las primeras décadas del siglo xx.

El primer autor a que nos referimos es Alfonso Reyes, quien da a luz su obra Ifigenia Cruel (1923); la segunda, Teresa de la Parra, quien, ya fuera del architexto dramático, evoca a la heroína euripidea con su novela Ifigenia o diario de una señorita que escribió porque se fastidiaba (1924).

En Ifigenia Cruel (1923), poema dramático con el que, de forma confesa, Reyes nos quiere hablar del deseo del ser humano de ejercer su libertad, el mexicano utiliza como hipotexto la Ifigenia en Táuride de Eurípides, si bien decide imitar a los clásicos en contar la historia mítica de una nueva manera ${ }^{22}$, innovando en función de las ideas que pretende comunicar. Así, la Ifigenia que da nombre a la obra, como su homónima euripidea, aparece como sacerdotisa de Ártemis en el reino de los Tauros, pero, en este caso, la heroína aparece aquejada de una desmemoria que le hace ignorar sus orígenes

${ }^{21}$ Miranda CANCEla, Elina (2006): 205.

${ }^{22}$ Carter, Sheila Yvonne (1980): 166. Un estudio completo en Mathus Torre, Carlos (1984). Véase, asimismo Teja, Ada María (2004): 237-273. 
familiares. En Táuride aparece Orestes, quien le descubre la historia de su familia, ante el horror de Ifigenia que se reconoce heredera de una estirpe maldita. Pese a la insistencia de Orestes, Ifigenia, símbolo del hombre que puede superar el destino mediante su capacidad de decisión, decide permanecer en Táuride al servicio de la diosa y, contraviniendo la versión euripidea, rechaza la posibilidad del regreso. Esta versión que Reyes innova respecto a la del trágico griego, se ha interpretado como motivada por las vivencias personales del autor: el exilio, la política mexicana, la muerte del padre y el rechazo a la posibilidad del regreso a su México nata ${ }^{23}$.

Por las mismas fechas en que Reyes escribe su Ifigenia Cruel, la autora venezolana Teresa de la Parra (1889-1936) retoma la figura de la Ifigenia que inmortalizara Eurípides para escribir una de las dos novelas que le dieron fama en toda América: Ifigenia o diario de una señorita que escribió porque se fastidiaba. Nuevamente Eurípides se encuentra en el hipotexto de la novela postmodernista de Teresa de la Parra, obra que sitúa la acción en época contemporánea. Se trata de un retrato crítico de la sociedad caraqueña de comienzos del siglo xx, estructurado en torno a la figura de la protagonista, María Eugenia (nombre buscado para evocar el de la Ifigenia clásica), quien, de regreso a Venezuela tras una estancia europea, reacciona contra la sociedad tradicionalista del momento, representada por la figura de su abuela, y se debate entre el amor del poco fiable Gabriel Olmedo, quien le ofrece la libertad que supondría llevarla a vivir a Estados Unidos donde iniciar una vida como escritora, o el matrimonio de conveniencia con el autoritario César Leal, opción por la que se decanta al final de la obra la protagonista en un sacrificio supremo que la acerca a la Ifigenia euripidea ${ }^{24}$.

Pese a que la obra sitúa la acción en los primeros decenios del siglo xx las referencias explícitas al hipotexto clásico ${ }^{25}$ se concentran especialmente en los paratextos, véase el capítulo titulado, Hacia el puerto de Áulide o el llamado Ifigenia, así como la imagen final de María Eugenia, sentada en una silla de piedra observando su vestido de novia, se compara explícitamente con la heroína euripidea, en un texto no exento de matices irónicos en el que, aun aglutinando la mitología griega y otras como la fenicia, la protagonista se considera preparada para el martirio, pura y virginal, como Ifigenia, pero no para ser sacrificada a Moloch, ni al dios ancestral de siete cabezas, sino al «Espíritu de sacrificio», desde ese momento su único amante y su perfecto esposo.

Variadas han sido las explicaciones que se dan a la elección final de la heroína de una autora que aunaba un cierto conservadurismo con indudables simpatías feministas. El crítico Aníbal González ${ }^{26}$ ha interpretado el final de la oba de de la Parra a la luz de los textos euripideos que presentan el rescate milagroso de Ifigenia en el momento del sacrificio y su posterior asignación al sacerdocio de Atenea. González interpreta la figura del personaje, así como la de la autora y su controvertida sexualidad, bajo el sig-

${ }^{23}$ Arenas Monreal, Rogelio (2004):114.

${ }^{24}$ Cf. Garrels, Elizabeth (ed.) (2008).

${ }^{25}$ Un estudio completo en Bailey Gutiérrez, Alberto K. (2010). Véase también GarCía GuAL, Carlos (2003): 147-168.

${ }^{26}$ GonZÁlez, Aníbal (2001): 66-85. Véase también PALACios, María Fernanda (2001), así como MoYA-RAGGIO, Eliana (1998): 161-171. 
no de Ártemis, como divinidad andrógina, con un lado salvaje y masculino. El destino posterior de María Eugenia sólo sería comparable al de Ifigenia si para el personaje de la venezolana se supusiera una virginidad espiritual posterior al matrimonio, una dedicación del personaje a la literatura avalado por la propia obra narrada ora como diario, ora como género epistolar. Desde este punto de vista, la obra sería aparentemente el retrato de la mujer escritora como víctima, pero en realidad postularía la imagen de la mujer escritora como poderoso generador de ficciones.

\subsubsection{Las Electras, Clitemnestras y Orestes}

También Electra, siguiendo la ficción que expusieron los tres trágicos atenienses, ha sido recreada en Iberoamérica, sin que se pueda distinguir siempre el texto de qué autor griego pesa más en la obra moderna, salvo en algunos casos en que el autor moderno hace referencia en el título de su obra a la Orestea de Esquilo ${ }^{27}$.

La figura de Electra ${ }^{28}$ se retoma con frecuencia para hablar de las relaciones familiares, para denunciar el lastre de la familia patriarcal tradicional o para revisar la figura de la madre, sin olvidar el tema de la traición y la venganza. En este caso, las recreaciones exceden el ámbito de la dramaturgia y hay importantes evocaciones de estas tragedias en el ámbito de la narrativa y de la poesía.

Como precedente, ya el brasileño Machado de Assis ${ }^{29}$, en el cuento titulado Pílades y Orestes (1903), había acudido al mito de los descendientes de Agamenón para hacer una adaptación paródica subversiva del modelo, que, de una amistad entrañable, lo convierte en una amistad interesada.

Pero en la dramaturgia iberoamericana se inicia el catálogo de Electras en los años cuarenta del siglo xx, con la obra Senhora dos Afogados (1947), del brasileño Nelson Rodrigues, seguida por la transgresora Electra Garrigó (1948) del cubano Virgilio Piñera.

Nelson Rodrigues sitúa la acción de su Senhora dos Afogados en Brasil y hace una relectura del mito con claves psicoanalíticas, con una crítica moralista de la sociedad carioca. Aunque escrita en 1947, la obra fue censurada y sólo se pudo montar en 1954, con gran división del público y diversos altercados en el estreno. En esta reelaboración del mito clásico, que reposa, asimismo, sobre el hipotexto del drama de O'Neill $A$ Electra le sienta bien el luto, la protagonista Moema-Electra odia a su progenitora sin motivo, por una rivalidad subliminal, que le impide la relación con el único hombre que ama, su padre. La hija Moema propiciará el adulterio de su madre, consiguiendo que su madre mate al amante y su padre a su madre. Finalmente, cuando Moema logra rehuir la imagen de su madre que la persigue desde los espejos, descubre que no puede cumplir su objetivo de ser la única mujer en la vida de su padre porque este ha muerto.

\footnotetext{
${ }^{27}$ PePe de SuÁrez, Luz (2009): 491-497.

${ }^{28}$ Estudiada en detalle por Campuzano, Luisa (2002) y Bravo De Laguna Romero, Francisco José, y Oliva CRUz, Juan Ignacio (1999): 201-218.

${ }^{29}$ Dos Santos, Edilson (2008).
} 
El renovador de la escena cubana Virgilio Piñera sitúa su Electra Garrigó $(1948)^{30}$ en un ambiente cubano, y la obra supone una crítica de las relaciones entre padres e hijos, en las que prima el deseo de perpetuarse sobre las relaciones afectivas. Este texto representa la entrada del teatro cubano en la modernidad, a través del sincretismo entre el gran mito clásico y el pensamiento, las tradiciones y el coloquialismo del habla cubana. Los principales personajes del drama griego se han trasladado a un contexto criollo, donde, en clave de parodia, aparece un Agamenón Garrigó alcohólico, una Clitemnestra marcadamente hipersexual, o una Antígona descreída y solitaria, para denunciar el matriarcado y el machismo presentes en la sociedad cubana. La integración del elemento autóctono se hace patente en elementos como el coro, representación del pueblo, que desgrana su canto a ritmo de Guantanamera, o del simbolismo sexual de la frutabomba típicamente cubana con la que es envenenada Clitemnestra.

Con un sentido muy distinto, ese mismo año, el argentino Omar del Carlo, representante del teatro católico, retoma el tema de Electra para intentar aunar el elemento griego y el cristiano, en Electra al amanecer (1948), dando con ello comienzo a una larga serie de reinterpretaciones de este mito en el teatro argentino. La obra, situada en la Grecia clásica por su autor, presenta, sin embargo, a los actores vestidos con trajes contemporáneos. Su personaje de Orestes busca el perdón y el olvido, frente a una Electra monolítica y sedienta de sangre, que, una vez que ha convencido al hermano y éste ha ejecutado el matricidio, queda sola y desamparada, tras la muerte de Orestes, en un final aleccionador que persigue trasmitir la idea de la inutilidad de la venganza ${ }^{31}$.

Siguiendo en Argentina, aparece la Electra (1952) de Julio Imbert, tragedia en medio acto que propone, frente a todos sus precedentes míticos, una Electra maternal y símbolo del amor cósmico ${ }^{32}$, en una obra que se adereza con múltiples alusiones a la literatura bíblica. Mucho más conocida dentro, asimismo, de la literatura argentina, encontramos El Reñidero (1962), de Sergio de Cecco. Este autor, que sólo conserva de entre sus personajes el nombre clásico para Orestes, partiendo de la Electra sofoclea sitúa la acción dramática en Palermo, un suburbio del Buenos Aires de 1905, para hacer una reflexión sobre la venganza, la infidelidad y la traición, en el marco histórico del cambio de la sociedad rural a la suburbana. En la obra, de Cecco trata de ver valores universales, comunes a la Atenas clásica y a la Argentina de comienzos de siglo. Treinta años más tarde, el también argentino Ricardo Monti, en La oscuridad de la razón (1993), vuelve la trama de la Electra clásica a un contexto local histórico, al recrear los hechos míticos en la Sudamérica de 1830. La obra cuenta, además de los elementos hipotextuales de los trágicos griegos, con un componente shakespeariano (Macbeth, Hamlet) y cristiano, oponiendo el fatum clásico a la esperanza, representada por la luz de la razón ${ }^{33}$. Menos conocida es Tiempo al tiempo, del argentino Carlos J. P. Pizzorno, que sitúa los hechos de la saga de Atreo en el mundo de la mafia. El

${ }^{30}$ Estudios sobre la obra en Depretis, Giancarlo (1994): 179-184; CERVERA, Vicente (1995): 149156; Gil Montoya, Rigoberto (2002); Matas, Julio (1989); Miranda Cancela, Elina (1990): 40-53; AguiLú DE Murphy, Raquel (2002): 80-92; RAmos Fernández, Carolina (2004): 471-477.

${ }^{31}$ Cf. Modern, Rodolfo (2002):113-128.

${ }^{32}$ Así Modern, Rodolfo (2002): 127.

${ }^{33}$ Cf. Arlt, Mirta (2000): 52-53. Un estudio completo en Bravo de Laguna Romero, Francisco Javier (1999). 201-218. 
argentino Omar Fantini presenta su Orestes (1998), adaptación personal de los textos clásicos, y su compatriota Javier Roberto González, en La declaración de Electra (1994, inédita) vuelve a la revisión psicoanalítica del mito, incorporando técnicas cromáticas del teatro expresionista.

La figura de Orestes ha sido especialmente tratada por el teatro mexicano a partir de los años 80. El mito se subvierte en la obra Hugo Argüelles, Los gallos salvajes (1986), donde un Orestes autóctono regresa al hogar para matar, no a la madre, sino al padre, y para sacudirse las Erinias mexicanas, las Tzitzimime, que le persiguen desde niño, aglutinando, una vez más, la mitología clásica y la indígena ${ }^{34}$. También es reseñable Retorna Orestes, del mexicano Miguel Barbachano Ponce, que ubica la acción en el ambiente de la revolución, con una lectura social del mito. Como señala María Sten ${ }^{35}$, hay dos obras teatrales mexicanas, Secretos de familia (1991), de Héctor Mendoza y Orestes parte (1984), de José Ramón Enríquez, que, alterando la historia mítica trasmitida por los clásicos, se centran en el tema innovador del incesto entre Clitemnestra y Orestes, propiciado por la reina de Micenas para mantener el poder. Pero mientras en la obra de Mendoza es Orestes el que tiene un impulso erótico freudiano hacia su madre, en la de Enríquez es la madre, masculina y poderosa, la que pretende desposarse con un Orestes afeminado, que, enamorado de Pílades, huye como el clásico, pero no porque sea perseguido por las Furias, sino en defensa de su identidad. Por lo demás, en la obra de Mendoza se juega con dos historias paralelas: la de los personajes míticos en la Micenas posterior a la caída de Troya, y, en el México actual, la historia de Cristina, hija de un empresario asesinado en extrañas circunstancias, que visita a una vieja amiga para descubrir los secretos familiares que dan nombre a la obra. El doble marco temporal es utilizado por el autor para mostrar al público la universalidad de los conflictos humanos. En fechas más cercanas, sin dejar la escena mexicana, encontramos la obra Orestes o Dios no es máquina (2000), del escritor y actor Miguel Ángel Canto. En ella, las Erinias del coro, representación de la conciencia, increpan al público, lanzándose físicamente sobre él. Obra amarga y de carácter ritual, se pregunta por el sentido de la religión y la moral, con la presencia de un Orestes que termina matando a la Erinias y, por tanto, asesinando su propia conciencia. En ¿Qué oyes, Orestes? (2006), de la directora escénica mexicana Juliana Faesler, la autora vuelve al mito del descendiente de Atreo para hacer una reflexión sobre el momento histórico actual: el hombre contemporáneo es un Orestes que ha matado a sus padres, el capitalismo y el socialismo, y se mueve en el vacío ante la presencia de una guerra injusta.

Recientemente, el cubano Yerandy Fleites Pérez toca el tema de la Electra clásica en Jardín de héroes (2009), desacralizando el concepto de héroe para hablar sobre las nuevas generaciones y su participación en la historia.

Referencia explícita al hipotexto esquileo aparece en la Orestíada actual (19381947), del mexicano Dagoberto de Cervantes, parcialmente inédita ${ }^{36}$, donde se moderniza la acción hasta el punto que las Euménides están representadas por la policía

\footnotetext{
${ }^{34}$ STEN, María (2003): 54.

${ }^{35}$ STEN, María (2003): 80-95.

${ }^{36}$ Sten, María (2003): 53.
} 
secreta, y en la obra del chileno Marco Antonio de la Parra en La tierra insomne o la Orestíada de Chile (1998), revisión en clave clásica de la reciente historia de Chile ${ }^{37}$.

Dentro del ámbito de la narrativa, destacan las evocaciones de Electra en la dominicana Aída Cartagena Portalatín, con Escalera para Electra (1969), en el que la autora establece un inimaginable paralelo entre la heroína clásica y una Electra quisqueyana que en la ficción está escribiendo la protagonista de la novela. Así encontramos varios niveles de referencia, la Electra de Eurípides, de la que se insertan abundantes intertextos, un viaje a Grecia de la protagonista y la trama de la Electra caribeña que esta está redactando, una historia de familia, incesto y crimen. En esta destaca la intención transgresora en la utilización del mito, una vez más, para poner en evidencia las concepciones clásica y caribeña de la familia patriarcal. Años después, también dentro del architexto narrativo, la colombiana Albalucía Ángel retoma la figura de la hija de Agamenón en Las andariegas (1984), en una búsqueda de la condición femenina a partir de los grandes mitos de la cultura occidental. ${ }^{38}$

En el género poético es reseñable la excelente Electra en la niebla, de la chilena Gabriela Mistral (inédita hasta 1991) ${ }^{39}$, quien nos muestra una identificación entre Electra y su hermano Orestes, hasta el punto de hacer a la heroína responsable principal de la muerte de Clitemnestra ${ }^{40}$ y donde Mistral se sirve del matricidio mítico para utilizar su habitual dialéctica leche-sangre. Asimismo relevantes son el poema Retorno de Electra (1984) de la mexicana Enriqueta Ochoa, y el poemario completo, con revisión feminista de los mitos, Electra, Clitemnestra (1986) de la cubana Magaly Alabáu.

\subsection{La saga tebana}

\subsubsection{El Edipo Rey}

Pese a ser el Edipo Rey el prototipo de lo trágico, si retomamos la opinión de Aristóteles, lo cierto es que la escena iberoamericana no ha vuelto con demasiada frecuencia los ojos a esta obras como hipotexto de nuevas realidades dramáticas y, cuando lo ha hecho, no ha sido para mostrar, como en el trágico ateniense, la grandeza del hombre enfrentado a su destino, sino que, bien ha servido para la reflexión introspectiva desde el complejo punto de vista del psicoanálisis, bien para caricaturizar en recreación del Edipo la figura de tirano, bien para subvertir el mito de forma irreverente.

En el primero de los casos encontramos la obra del dramaturgo mexicano Salvador Novo, que se aleja de sus inicios dramáticos realistas con Yocasta o casi (1961), revisión del Edipo Rey sofocleo, en la que se propone un complicado juego intertextual, que pretende una reflexión entre lo real y lo ficticio, sin que se excluya la presencia de otros mitos griegos, marcados todos ellos por la impronta del psicoanálisis ${ }^{41}$.

\footnotetext{
${ }^{37}$ Cañizares Ferriz, Patricia (2002): 647-660.

${ }^{38}$ Cf. Campuzano, Luisa (2002); Osorio, Myriam (2010).

${ }^{39}$ Figueroa, Ana (2001a): 51-62; FigueroA, Ana (2001b): 59-71.

${ }^{40}$ Molloy, Sylvia (1991): 107-124.

${ }^{41}$ Dauster, Frank (1985):13-22.
} 
Una visión caricaturesca del personaje sofocleo aparece en El tiempo de la plaga, escrita en 1968 por el cubano Abelardo Estorino. El drama, desde el propio paratexto, hace referencia a la mítica peste de Atenas del drama de Sófocles, recreando la figura del rey de Tebas para hacer una denuncia del dictador en el contexto del Caribe de finales de los años cincuenta. Como ha señalado la profesora Miranda Cancela ${ }^{42}$, Estorino no pretende la reconstrucción de la tragedia griega y ni siquiera conserva los nombres clásicos, sino que alude a los personajes de la obra por los nombres de sus respectivos oficios, y aunque no hay referencias precisas, contextualmente se deduce que la obra se sitúa en la Cuba de entre 1952 y 1959, la época de la dictadura de Batista, con quien se identifica al Presidente protagonista. La plaga a que hace referencia el título, a diferencia de la peste ateniense, es una epidemia de crímenes sin fin, para cuya investigación el presidente, ofuscado por su propia idea del poder, termina poniendo trabas. La obra continúa formalmente elementos de la tragedia clásica, como la presencia del coro o el relato del mensajero, sin embargo, se trata de una visión transgresora del elemento trágico, con un protagonista, el presidente tirano, que, al contrario que el Edipo sofocleo, pone trabas a la búsqueda de la verdad, y para el que no hay anagnórisis redentora, ya que muere obcecado en las bondades de su propio sistema. Es, por lo demás, el protagonista un personaje grotesco y plano, al que Estorino dota de alguna de alguna de las características del tirano platónico ${ }^{43}$.

En la última década del siglo, Edipo ha sido revisitado de forma irreverente, entre otros casos, por la relectura irónica del chileno Benjamín Galemiri con su Edipo Asesor $(1991)^{44}$ y por el humor centrado en el tabú del incesto, del ecuatoriano Peky Andino, con su Edipo y su señora mamasita (1998).

\subsubsection{Las Antígonas}

Sin duda, la obra más recreada en Iberoamérica, de ente toda la tragedia ática, es la Antígona de Sófocles ${ }^{45}$. No hay duda de que la oposición de individuo ante la tiranía es tema que ha calado hondo en el alma americana, habida cuenta de la propia historia de las numerosas repúblicas del subcontinente y sus sucesivos regímenes dictatoriales. Asimismo, el tema de las debidas honras fúnebres enlaza bien con el drama de los desaparecidos en dictaduras como la argentina ${ }^{46} \mathrm{o}$ la chilena.

Es, efectivamente, a partir de los años cincuenta y principios de los sesenta cuando emergen con fuerzas las Antígonas iberoamericanas, muchas de ellas con un evidente contenido político. De ellas recogemos un conjunto de obras, que, con seguridad, no agotará, ya no sólo las recreaciones y adaptaciones, sino los numerosos montajes de la Antígona sofoclea llevados a la escena americana.

${ }^{42}$ Miranda Cancela, Elina (2006b):99-110.

${ }^{43}$ Miranda Cancela, Elina (2006b).

${ }^{44}$ PARDo, Karina (2004).

${ }^{45}$ El estudio indispensable sobre el tema es el de Pianacci, Rómulo E. (2004): 459-486 y la subsiguiente monografía del mismo autor, PiAnACCI, Rómulo E. (2007). Previamente había tratado el tema VILANOva, Ángel (1999): 137-150. Como marco general cf. el ya clásico estudio de STEINER, George (1987). Véase también Bañuls Oller, José Vicente; Morenilla Talens, Carmen (2008): 79-89.

${ }^{46}$ González Betancur, Juan David (2010): 75-85; Moreno, Iani del Rosario (1997):115-129. 
Encabeza cronológicamente la relación el drama Antígona Vélez del argentino Leopoldo Marechal, escrita en $1952^{47}$. Obra de ricos juegos intertextuales, en el que tienen su peso no sólo el texto sofocleo, sino distintas adaptaciones previas del mismo, algunos autores explican el texto en su contexto histórico dentro de la historia de argentina, mientras que otros pretenden darle un sentido más universal que lo acercaría a Sófocles. La acción dramática se localiza en la Argentina del siglo xIX, durante la llamada conquista del desierto en 1879 , momento en el que surge la confrontación entre la ley de la llanura, equiparable a las leyes humanas del trágico griego y la ley de Dios, en Sófocles los óypa $\propto$ ol vópol, que simbolizan la oposición civilización (representada por el cristianismo), frente a barbarie (representada por la figura del indio). Marechal inicia así una numerosa serie de obras en que la acción del mito griego se traslada a las luchas entre indígenas y blancos dentro de la historia de Iberoamérica.

En 1958 el nicaragüense Rolando Steiner escribe Antígona en el Infierno, obra que, pese a situar la acción en un escenario neutro, remite a la realidad de Nicaragua en el momento, por las referencias a las revueltas políticas, a las torturas y a la crueldad con que se obliga a los condenados a cavar su propia fosa. Aquí Antígona, intuyendo que su hermano Polinices, que revisa las tropas rebeldes en la frontera, ha sido asesinado, decide demostrarlo encontrando su tumba y con una acción contraria a la de la heróina de Sófocles: desenterrar el cadáver para dejar patente el crimen. Ello le conlleva la sentencia de muerte por parte de Creonte, que finalmente perecerá en la revuelta popular con el nombre de Antígona en los labios.

El brasileño Jorge Andrade es el autor de Pedreira das almas, estrenada en el año 1958 , una obra que puede calificarse de «tragedia social» y que recrea los hechos de la Antígona sofoclea ${ }^{48}$ trasladados al Brasil de 1842, en la aldea que da nombre al drama. En Pedreira las minas de oro, que eran la riqueza del pueblo, están agotadas y las jóvenes Mariana y Clara se plantean abandonar la localidad en busca de una nueva vida, guiadas por el novio de Mariana, Gabriel, nuevo Hemón, jefe de los insurrectos de la guerrilla. Doña Urbana, que representa la tradición y el orden, se niega a abandonar a sus muertos en este proyecto de éxodo. El delegado policial Vasconcelos, que pretende reprimir el movimiento liberal, decreta el estado de sitio y se niega a que se dé sepultura al joven Martiniano (Polinices), hijo de doña Urbana, y muerto en difíciles circunstancias, hasta que Gabriel-Hemón, que se ha refugiado en una gruta, acceda a entregarse. Finalmente, ante la rebelión del ejército y de las mujeres, Vasconcelos abandona el lugar y sus habitantes serán conducidos por Gabriel en búsqueda de una nueva vida, excepto Mariana, que permanecerá finalmente en Pedreira fiel a sus muertos. En definitiva, representación de un conflicto del pueblo frente al estado.

El argentino Alberto de Zavalía, en El límite (1958), nos presenta una Antígona tucumana, con la recreación dramática uno de los hechos acaecidos en las guerras

${ }^{47}$ Estudios en Biglieri, Aníbal A. (2009): 111-122; Croce, Marcela (2000-2001):203-238; Huber, Elena (1974):149-156; Kuehne, Alice de (1975):19-27; Pérez Blanco, Lucrecio (1984): 143-172; RuIZ Pérez, Ángel (1999): 393-397; Vilanova, Ángel (1999); Vilanova, Ángel (1996): 395-403. Desde el ámbito de la literatura comparada cf. SeVILLA ListerRI, Javier (2006).

${ }^{48}$ Cf. Vilanova, Ángel (1999). 
civiles argentinas del siglo XIX. El joven Marcos de Avellaneda, de 28 años, intelectual antirrosista, fue ejecutado con crueldad y su cabeza fue clavada en una pica en la plaza de Tucumán, el 3 de octubre de 1841, hasta que la matrona tucumana doña Fortunata García, junto con uno de los hombres de Oribe, escondió la cabeza en su casa, para después darle cristiana sepultura en un nicho del convento de San Francisco. Se trata de una obra en dos actos, de inspiración histórica, y su título hace referencia al dilema moral que superan algunos individuos, sin claudicar aunque estén al límite de su resistencia, como los héroes clásicos. De nuevo historia local y mito griego se unen en la plasmación de la grandeza ética.

El argentino David Cureses, con La cabeza en la jaula (1963), retoma el tema sofocleo trasladando la acción a la Colombia de la época de la emancipación, centrándose en la figura del héroe nacional José Antonio Galán, ajusticiado en 1782, y cuyo cuerpo fue desmembrado en Bogotá, con la exposición ejemplar de su cabeza, que da nombre a la obra. En la ficción, las mujeres familiares del muerto - trasunto de Antígona, Ismena y el coro de tebanas de Sófocles - se unen para reunir los miembros dispersos de Galán y darles cristiana sepultura, en una tensión entre la intromisión de lo público y los derechos individuales que ha analizado Claudia María Biasoli ${ }^{49}$. Finalmente, estas mujeres, continuadoras de la heroína tebana, pagarán su acto de piedad con el sometimiento y la enajenación de su cuerpo, y, finalmente, con el precio de su vida.

Muy diferente carácter tiene el drama La fiesta de los moribundos (1966) del venezolano César Rengifo. Obra grotesca y abundante en humor negro, se puede definir por su carácter visionario, ya que va a denunciar la pérdida de los deberes sagrados para con los muertos al sacar a escena un supuesto comercio ilegal de cadáveres, muchos años antes de que existiera comercio de órganos para trasplantes o de que la trama de las vacas locas dejara al descubierto que se podía utilizar materia muerta para fabricar piensos para animales ${ }^{50}$. La acción de sitúa en Oklahoma (Estados Unidos) donde una empresa se dedica a comerciar con cadáveres. La empresa es denunciada por la anciana Antígona Sellers de Missouri, que reclama el cadáver de su hermana gemela muerta a los 80 años. Las ancianas se habían hecho recíproca promesa de otorgarse unas humildes pero dignas honras fúnebres y Antígona pretende cumplir su promesa. Finalmente sólo logrará recuperar la mitad de cadáver y se negará a cobrar el cheque con la indemnización de dos millones de dólares que le habían entregado. En definitiva, una denuncia de la deshumanización de la vida y la muerte y de la conversión del individuo en mera mercancía.

Del año 1968 data la composición del drama Atrás queda el polvo, obra del escritor cubano exilado José Triana. El hecho de que la obra permanezca inédita ha dificultado durante años su análisis, que, sin embargo, ha llevado a cabo, después de la revisión del texto mecanografiado, la profesora Carmen Bosch ${ }^{51}$. La obra muestra

${ }^{49}$ BiAsoli, Claudia María (2007), ponencia en la Jornada de Debates sobre Literatura Latinoamericana y Estudios de Género, Universidad de Buenos Aires, octubre de 2007. La investigadora desarrolla el tema en el marco de una beca adscrita a la Cátedra de Historia del Teatro Universal (UBA).

${ }^{50}$ Véase una vez más el indispensable estudio de Pianacci, Rómulo (2004): 459-486.

${ }^{51}$ Bosch, María del Carmen (1999): 271-280 y «Una Antígona cubana: atrás queda el polvo» (1997), anunciado para las Actas del congreso internacional de literatura iberoamericana y tradición clásica Barcelona-Valencia, 21-25 de octubre de 1997. 
una mezcla de las mitologías clásica y afrocubana, presente asimismo en otras obras del autor, y su trama, de carácter marcadamente metateatral, se estructura en torno a la representación de una Antígona por una humilde compañía de teatro. El título de la obra representada, «Contra Hantígona», da cuenta de la intención subversiva respecto al mito clásico. En el drama cubano, al contrario que en el ateniense, José Miguel (Creonte) da orden de enterrar a Julio (Polinices), pero Clara Luz (Antígona), en quien también se ve la huella del personaje de Anouilh, le desprecia y se niega y le maldice, siempre apoyada por Ignacio (Hemón), con quien, de nuevo subvirtiendo los esquemas de amor y muerte, es descubierta en la cueva como nido de amor. Esta Antígona desafiante, que sólo espera en lo bueno que saldrá de la revolución, triunfará cuando el pueblo exaltado por el odio, linche a Jose Miguel (Creonte).

También en 1968 el mexicano José Fuentes Marel lleva a escena La joven Antígona se va a la guerra, desvarío dramático en dos actos, obra en la que de nuevo se plantea la decisión individual frente a la obediencia ciega, en este caso no la desobediencia al estado, sino al partido. En ella Antígona es el alias de una joven guerrillera que debe pasar su prueba de fuego al poner una carga explosiva en la Estación Norte. Finalmente, la joven aborta el atentado al darse cuenta de la presencia de un niño que moriría si se produce la deflagración. Como ha resaltado Pianacci ${ }^{52}$, las posiciones inflexibles de Antígona y los miembros de la célula del partido recuerdan a las de la Antígona y el Creonte clásicos. Por lo demás, en el comienzo de cada uno de los actos se cuenta con los intertextos de la tragedia sofoclea: el primer estásimo de la Antígona antes del primer acto y el relato del mensajero, más los versos 450-460 y parte de la despedida del episodio cuarto en boca de la princesa tebana. En suma, la obra supone una reflexión acerca de si el fin justifica los medios y sobre la libertad de conciencia frente a la obediencia ciega.

También en 1968 el puertorriqueño Luis Rafael Sánchez presenta, La pasión según Antígona Pérez. La acción trágica se sitúa en la República de Molina, con la que se puede simbolizar cualquier país de Hispanoamérica. La República está sometida a la tiranía de un dictador, Creón Molina, que busca aplastar el movimiento revolucionario. Así el llamado Generalísimo Creón no vacila en utilizar todos los medios para sofocar los intentos de liberación del país. En este contexto, una Antígona, apellidada con simplicidad Pérez — símbolo de cualquier mujer que se levanta ante la opresión_- es acusada de haber rescatado los cadáveres de dos insurgentes asesinados por el régimen y mantenidos insepultos con afán ejemplarizante. Esta Antígona americana, logra, como la clásica, rescatar y enterrar los cadáveres, pagando con la prisión y la tortura su acto heroico, mantenido con su negativa a confesar el lugar de la sepultura. Son varios los personajes que interrogan a la protagonista, siempre íntegra y acusadora del tirano. Además de la oposición entre la mujer rebelde y del tirano dictador, aparece una crítica a otros estamentos, como el eclesiástico, representado por un Monseñor Bernardo Escudero, representante del Vaticano y aliado de Creón. Antígona Pérez, como su precedente sofoclea, es ajusticiada, en este caso mediante fusilamiento, mientras los periodistas mancillan su memoria al afirmar que ha muerto tras claudicar, confesando ante el tirano.

\footnotetext{
${ }^{52}$ Pianacci (2004):476.
} 
Asimismo en 1968 el dominicano Franklin Domínguez y Hernández escribe una sorprendente obra llamada Antígona-Humor. Dentro del campo de la architextualidad hemos de reseñar el drástico cambio de género literario que pasa de la tragedia a la comedia. Aquí Hemón y Antígona son un acomodado matrimonio, Enrique e Ingrid, con el que convive desde tres meses atrás el cuñado gorrón, Pepe-Polinices, abandonado por su novia rica (Yolanda-Argia) y que es origen de buena parte de las discusiones domésticas. Ingrid, actriz retirada, tiene que hacer una reentré teatral la noche en que se desarrolla la acción dramática, encarnando, precisamente, el personaje de la Antígona sofoclea. Como comedia burguesa y comercial que es, el conflicto se resuelve felizmente, con la reconciliación de Pepe con su novia, el triunfo de Ingrid en la escena, y, consecuentemente con el ideario burgués, su renuncia al teatro en aras a su dedicación a la familia y a la superación de su crisis matrimonial. Se ha hablado de terrorismo textual en la obra ${ }^{53}$, de atentado a la sacralidad de un texto canónico. Lo cierto es que de él se deduce la defensa de unos valores tradicionales respecto al rol de la mujer en el ámbito familiar.

De nuevo el brasileño Jorge Andrade retoma el hipotexto sofocleo para construir su obra As Cofrarias (1970), que sitúa la acción en un momento importante de la historia de Brasil, 1789, época de la Inconfidência Mineira, donde se insiste en el conflicto entre libertad individual y la opresión de las instituciones, haciendo una crítica del estamento religioso, representado en la obra por las cofrarias - o cofradías - que le dan nombre, y que se niegan a enterrar el cuerpo del personaje de José por no ajustarse a las diversas normas establecidas. La decisión de su madre Quitéria - nueva Antígona- es contraria a la del personaje sofocleo, ya que decide dejar insepulto el cuerpo de su hijo para dejar en evidencia la falta de piedad de las instituciones religiosas. No se excluye, asimismo, aunque la acción se sitúe en una fecha histórica, que la crítica se extienda a la época contemporánea de la obra, la dominación militar del Brasil de los años sesenta y setenta ${ }^{54}$.

Avanzada precisamente esta década, el venezolano José Gabriel Núñez, autor de una dramaturgia con fuerte simbolismo, a veces identificada con el teatro del absurdo, también estrena una Antígona (1978).

Golpes a mi puerta (1988) del argentino Juan Carlos Gené reflexiona sobre la religión y la fe en el contexto de un régimen totalitario. Así, la obra trata de un país imaginario de Sudamérica, maltratado por la guerra civil, donde un rebelde huido se acoge a sagrado. La oposición entre el político Creonte y las dos monjas que habitan la casa donde el fugitivo se ha refugiado da pie a una reflexión sobre la división entre la Iglesia oficial y la Iglesia comprometida y las contradicciones que ello conlleva.

La Antígona Furiosa de la argentina Griselda Gambaro, sale a la luz en $1989^{55}$. Aunque en la obra no se alude explícitamente al contexto histórico y social en el que se desarrolla la acción, tácitamente se hace que el público tenga conciencia de que se

\footnotetext{
${ }^{53}$ García, William (1997): 15-29.

${ }^{54}$ Moreno, Iani del Rosario (1997): 115-127, especialmente: 116-118.

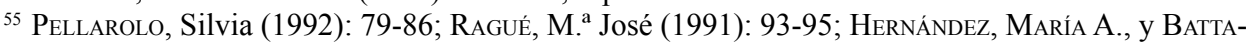
GLIORI, G .(1994): 90-95; KöNIG, Irmtrud (2002): 5-20.
} 
trata de una situación vivida en tiempos recientes: el drama de los desaparecidos en la dictadura. Los personajes en escena se reducen a tres, Antígona, el Corifeo, y Antínoo, al que se suma una carcasa en la que, en ocasiones se introduce el Corifeo. Asimismo, en ocasiones, Hemón habla por boca de Antígona. La acción comienza con una vuelta atrás, Antígona, ahorcada, se quita el lazo del cuello y establece un diálogo con los otros dos personajes que remite a los hechos anteriores a la muerte de la princesa tebana. Corifeo y Antínoo se burlarán sin piedad de Antígona, que será calificada de «loca», como lo fueron las madres de la Plaza de Mayo $^{56}$ en el proceso dictatorial argentino. Asimismo, la referencia a los que no están con los vivos ni con los muertos remite a la entonces reciente realidad argentina de los desaparecidos. La princesa volverá a la tumba antes de que acabe la obra y desde allí narrará el final de la historia: ella siempre enterrará a Polinices, aunque ella naciera mil veces y él muriera mil veces, y siempre, indefectiblemente, sería castigada. La obra, hipertexto paródico e irónico del texto sofocleo, deconstruye el discurso del poder por parte del personaje femenino y plantea la transgresión como liberación ${ }^{57}$, sin embargo, cierra la esperanza del castigo para el tirano y se manifiesta desconfiada en la lucha contra el poder. En definitiva, la obra manifiesta una condena de la dictadura y una gran desesperanza en el futuro.

Muy interesante es la Antígona que se representó entre los meses de febrero y abril de 2000 en Magdalena del Mar (Perú) por el grupo Yuyachkani ${ }^{58}$, en versión de José Watanabe, dirigido por Miguel Rubio e interpretado por Teresa Ralli. El propio autor afirmaba a la prensa que la idea de llevar a cabo esta Antígona partió de la visión de una fotografía en una exposición en la que se representaba a una mujer enlutada atravesando a la fuga los arcos de la Plaza de Armas de Ayacucho. Esta imagen evocó la imagen de la Antígona clásica de sus lecturas juveniles. Conscientes del estado de violencia que había vivido su país, de los desaparecidos y de sus familiares que buscaban incansables el lugar en que reposaban sus cuerpos, se animaron a hacer una representación de una versión libre de la Antígona de Sófocles en esta clave. Para llevar a cabo el proyecto sus creadores se entrevistaron con muchas mujeres, parientes de desaparecidos, que se habían tenido que enfrentar solas al poder para poder indagar sobre sus padre, esposos e hijos. «Recurrir a Antígona es una manera de apelar a la memoria histórica universal para buscar en ella señales que nos ayuden a entender nuestra propia tragedia», afirmaba Watanabe. Así, aunque en la obra no se cita explícitamente, está claro que la acción se sitúa en Lima y que la figura de Creonte remite a la de Vladimir Montesinos. En cuanto a la particularidad de la versión de esta Antígona Unipersonal, estriba en que la misma actriz se desdobla y hace los papeles de un narrador que conoce la historia, de Creonte, del mensajero, de la propia Antígona y finalmente revela su verdadero rostro, es Ismena, la hermana cobarde («yo soy la hermana maniatada por el miedo», dice la protagonista) que prefirió callarse ante la injusticia y que finalmente se

${ }^{56}$ BonacCorsi, Nélida, Garrido, Margarita (1997):143-150.

${ }^{57}$ Cf. ZeCChIn dE FASANo, Graciela (2009):703-709.

${ }^{58}$ Muy recientemente se ha presentado un trabajo de investigación en el Doctorado de Artes Escénicas de la UAB por parte de LuQue Bedregal, Gino (2009), con el título de «La persistencia de la memoria: violencia política, memoria histórica y testimonio en Antígona de José Batanabe y el grupo Yuyachkani», que se puede consultar en la web http://ddd.uab.cat/pub/trerecpro/2009/hdl_2072_40657/ Treball+de+recerca+-+Gino+Luque+Bedregal.pdf 
arrepiente y es redimida. Así esta versión de la tragedia nos enfrenta a las dos posibles posturas de la mujer peruana ante una situación de terror político. La obra está dedicada «a todas aquellas mujeres que han sufrido en carne propia la violencia de la guerra interna que azotó al Perú en años recientes»».

El argentino Jorge Huertas presenta en AntígonaS [sic] , linaje de hembras (2001) una reflexión política mediante la evocación de una Argentina esencial ${ }^{59}$, en la que es fundamental el protagonismo del río, que oculta los cadáveres de los desaparecidos, y en la que aparecen personajes de la historia política y cultural del país, como Eva Perón, «la Embalsamada Peregrina», o el espectro de Jorge Luis Borges.

Recientes también son las obras de la argentina Hebe Campanella, con Antígona... con amor (2002) y de la la chilena Daniela Cápona Pérez, Antígona, historia de objetos perdidos (2002).

Uno de los últimos hipertextos de la Antígona clásica (pero en el que también subyacen los textos de Brecht y Anouilh) es la obra de la dramaturga mexicana Perla de la Rosa, Antígona, las voces que incendian el desierto (2005), en la que la acción se sitúa en época actual en una ciudad Tebas, trasunto en realidad de Ciudad Juárez y en la que se denuncia la terrible violencia contra las mujeres y el drama de la existencia de más de doscientos cadáveres de mujeres desaparecidas, cuya existencia niegan las autoridades. Esta Antígona mexicana se levanta contra el decreto de Creonte que niega la desaparición de las mujeres y prohíbe su búsqueda, y ayudada por Hemón, logra localizar el cadáver de la última víctima, hasta que ambos son descubiertos y ametrallados. La búsqueda de esta Antígona es un aviso frente al olvido de las víctimas de la violencia ${ }^{60}$.

También como denuncia política aparece Antígona (2006) de la colombiana Patricia Ariza, escrita para el grupo teatral La Candelaria, que lleva a escena la situación de las mujeres de Colombia, víctimas de la guerra y del machismo.

Inéditas permanecen Antígona ino!, de la argentina Yamila Grande (escrita en 2003), Antígona y Actriz, del colombiano Carlos Eduardo Satiazábal (escrita en 2004), Antígona, del cubano Joel Sáez (escrita en 1993), Los motivos de Antígona, del mexicano Ricardo Andrade Jardí (escrita en 2000) y Antígona, de la peruana Sarina Helfgott (escrita en 1964) ${ }^{61}$.

No se puede acabar la relación de las Antígonas latinoamericanas sin hacer referencia a la que fue una de las más tempranas recreaciones de mito sofocleo, si bien fuera del ámbito de la dramaturgia: Se trata de la novela del Nobel colombiano Gabriel García Márquez La Hojarasca $(1955)^{62}$, que traslada los hechos al universo de Macondo. La referencia al texto sofocleo es tan explícita, que García Márquez inicia la obra con una cita del primer episodio de la Antígona a modo de paratexto ${ }^{63}$. En la ficción, que constituye una interpretación social del mito griego, un Creonte tripartito,

${ }^{59}$ PINKLER, Leandro (2002). En el I Encuentro Internacional sobre Traducción y Tradición de autores griegos y latinos en América Latina, Madrid, UAM, 11-14 de enero de 2011, la profesora Lidia Gambón presentó la ponencia: «Huellas clásicas en el teatro argentino: Jorge Huertas».

${ }^{60}$ Así en Pianacci, Rómulo (2009) : 499-507.

${ }^{61}$ Cf. Pianacci, Rómulo (2007).

${ }^{62}$ Burguera Nadal, María Luisa (1997): 409-416.

${ }^{63}$ Se trata de la traducción de José Alemany, Las siete tragedias de Sófocles, traducidas al castellano por José Alemany Bolufer, Madrid, Hernando, 1921. 
representado por el alcalde, el cura y el propio pueblo, niega la sepultura a un médico local, un inadaptado social que se había negado a curar a los afectados por el temporal que da título a la novela, y cuyas honras fúnebres serán reclamadas por una Antígona asimismo tripartita, representada por el personaje del coronel, su hija y su nieto ${ }^{64}$.

\subsubsection{Los Siete contra Tebas}

La tragedia de Esquilo que narra el enfrentamiento entre los dos hijos varones de Edipo ha sido seguida con gran fidelidad por el dramaturgo cubano Antón Arrufat ${ }^{65}$, hasta el punto de que, en algunos casos, podría pensarse que nos encontramos ante una traducción de la obra del ateniense. No obstante el respeto de Arrufat por el texto de Esquilo, al que incorpora elementos de Las Fenicias de Eurípides, y la falta de elementos autóctonos cubanos introducidos para la actualización del texto - a diferencia del caso de otros dramaturgos caribeños coetáneos - la revisión de Los Siete contra Tebas (1968) que lleva a cabo Arrufat en su obra homónima, se sintió como una actualización del tema, hasta el punto de que el drama, premiado por la UNEAC, fue objeto de censura y condenado al ostracismo, dada que la presencia de un coro que duda y se cuestiona la situación entre los dos hermanos — que simbolizan a los cubanos de la isla y a los del exilio - se interpretó como un hecho contrarrevolucionario ${ }^{66}$.

En general, es reseñable que las acciones que en la obra de Esquilo aparecen narradas por boca de un tercero, en la de Arrufat tienen lugar sobre la escena, como el enfrentamiento entre Etéocles y Polinices, así como la duplicación del personaje del mensajero de Esquilo, en las figuras de dos espías, que intensifican ${ }^{67}$ la acción dramática.

\subsection{Las Medeas}

Como otrora hiciera Eurípides al mostrar la doble desgracia de ser mujer, distinta y extranjera, son numerosos los dramaturgos iberoamericanos que han retomado la historia de la princesa de la Cólquide para hablar, sobre todo, de mujeres marginadas. Esta marginación puede darla la raza (y así aparecerá en diversas ocasiones la figura de la india, la mulata o la negra), las condiciones sociales de pobreza extrema o exclusión, la presencia del narcotráfico, la inmigración, o el contraste entre la vida rural y la civilización urbanita. El problema de la extranjería aparece ya en La larga noche de Medea (1949), del argentino Álvaro Corrado. En este drama el asesinato de Medea representa un acto supremo de amor hacia unos hijos destinados a una vida de sufrimiento por parte de una Medea acorralada por la xenofobia ${ }^{68}$.

${ }^{64}$ Un estudio en Bosch, María del Carmen (1999): 271-280.

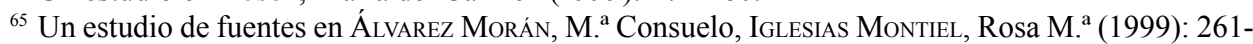
270. Cf. También los numerosos estudios de Barquet, Jesús J. (2002b); (1999): 19-33; (2000):59-69; (2002a) y el trabajo de Miranda CAncela, Elina (2006a). Recientemente, Mir, Andrés (2007) y CABrera Ortega, Yoandy (2010).

${ }^{66} \mathrm{Cf}$. La tesis doctoral de Pérez Asensio, Magdalena (2009), presentada en la Universidad de Murcia.

${ }^{67}$ BArquet, Jesús J. (1995): 74-87.

${ }^{68}$ Cantarela, Eva (2009): 47. 
La marginación a causa de la raza aparecerá en la figura de la india en la obra del peruano Juan Ríos, La selva (1950), en la del mexicano Jesús Sotelo Inclán, Malintzin (Medea Americana) (1957), en la de los argentinos David Cureses, La frontera (1960), Alberto Dragó, La Navarro (1980), José Luis Alves, La Hechicera (1997), Suellen Worstell, Medea del Paraná (2004) y en la del chileno Juan Radrigán Medea Mapuche (2000).

La primera Medea india aparece en 1950, fecha en que el peruano Juan Ríos escribe el drama La selva, obra en verso en tres actos, con la que gana el premio Nacional de Teatro. Se trata de una recreación de la historia de Jasón y Medea, ambientada en la época de la conquista española del Nuevo Mundo. El personaje masculino es un capitán de las tropas españolas enamorado de la hija de su captor indígena. La joven, nueva Medea, no duda en matar a su hermano y en engañar a su padre para conseguir la liberación del capitán. Una vez en la civilización sigue matando para proteger a su amado y cuando se tiene que enfrentar con una muchedumbre sedienta de venganza mata a sus hijos para evitarles una dolorosa agonía y ella se suicida. El capitán se une a ella con su propio suicidio ${ }^{69}$. La obra hace un uso innovador del flashback y tiene una versificación en metros variados de gran calidad.

En 1957, el mexicano Jesús Sotelo Inclán toma la figura de Medea, para referirse a un personaje, en este caso, histórico, de la conquista americana: Malintzin, La Malinche o, tras ser bautizada, doña Marina, la desdichada amante india de Hernán Cortés. Imagen tan controvertida como estigmatizada, por la ayuda que prestó a los españoles, sin embargo, resulta una inevitable referencia simbólica de la nación mexicana. Así, Sotelo Inclán escribe Malintzin: Medea Americana, Drama en tres actos en verso y prosa, haciendo un paralelismo entre la india Malinche, enamorada y colaboradora del caudillo invasor y madre de su hijo, y la princesa de la Cólquide euripidea.

También el conflicto del indio se plasma en la obra del argentino David Cureses $L a$ frontera $(1960)^{70}$. En ella la acción se sitúa en Coliqueo, provincia de Buenos Aires, en los finales del siglo XIX, la llamada época de la conquista del desierto. No me parece baladí que el nombre de la localidad bonaerense evoque fónicamente el de la Cólquide clásica, así como que los nombres de los protagonistas el capitán Jasón Ahumada y la indígena Bárbara continúen por su forma o su significado los del mito griego. En este caso, una vez que Bárbara, como su precedente mítica, ha salvado al capitán, la pareja interracial adoptará dos niños Botijo y Huinca. Al crecer ésta, que, en realidad, es hija de un capitán, Jasón se enamorará de ella y amenazará a Bárbara con quitarle los hijos nacidos de su unión para criarlos en la civilización. La india se servirá de la astucia para matar a Huinca, su hija adoptiva y su rival, en un trágico desenlace al conflicto entre el mundo salvaje, representado por el campo, y la civilización, representada por la ciudad.

El argentino Alberto Dragó retoma el mito en La Navarro (1980), que sitúa la acción en la localidad de Luján, provincia de Buenos Aires, en la década de los años

\footnotetext{
${ }^{69}$ Morris, Robert J. (1974): 81-95, especialmente 87-88.

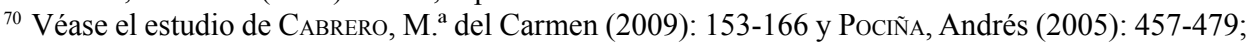
asimismo, recientemente, ZAYAS De Lima, Perla (2010): 10-11, quien incide en la exaltación del mundo indígena en esta obra de Cureses, y Bravo de Laguna Romero, Francisco J. (2010): 131-138.
} 
veinte. La protagonista, que continúa el nombre de la heroína clásica, es Medea, pero una Medea concreta, Medea Navarro. Amante apasionada, calificada de «animal sexual», también, como su precedente clásico, presenta en la obra dotes de brujería. Unida en secreto a Juan Cruz Aldao, hijo de un dirigente político de la ciudad, le ha dado dos hijos, ya adolescentes. Medea, que en el pasado mató a su padre, no vacila en hacer matar a su hermano creyendo que amenaza la vida de su hombre. El enfrentamiento entre Medea y el padre de Juan Cruz en el tercer cuadro evoca el agón entre Medea y Creonte de la obra de Eurípides. Finalmente, Medea, al saber que Juan Cruz la abandona para unirse con una mujer bien situada socialmente que le ayude en su ascensión política, aunque se plantea por un momento el filicidio, acaba matando por su propia mano al amante traidor.

La presencia indígena aparecerá, ya en fechas recientes, en obra del argentino José Luis Alves La Hechicera (1997). Ubicada la acción en el Tucumán de la época de la colonización española, presentará el conflicto racial y religioso con un choque entre las supersticiones y rituales indígenas y el poder dominante de la Inquisición. La protagonista, Medea González, que hereda el nombre y la condición de maga de su precedente griega, y que, como ella, traicionará a los suyos por amor, se opone a las figuras ambiciosas de la blanca Laurencia y del fanático inquisidor, sin olvidar la presencia innoble de Diego-Jasón, oportunista que se ha enriquecido mediante la denuncia de herejía de ricos hacendados. Obra de la que se ha señalado su riqueza intertextual, esta Medea González se asemejará a la de Sófocles en la decisión de la venganza ${ }^{71}$.

De nuevo a tiempos de la conquista española nos lleva la obra del chileno Juan Radrigán, Medea Mapuche (2000). Situada la acción en el Arauco, nos traslada la historia de la mapuche Kütral, que, como Medea, extranjera, bárbara y maga, llegará al infanticidio movida, en este caso, no por celos ni despecho, sino por orgullo de raza. Obra que presenta abundante material del hipotexto euripideo, tiene también su base en la Araucana de Ercilla y mezcla, como tantas otras relecturas de los clásicos hechas en Iberoamérica, los elementos clásicos — presencia de un coro- con las rogativas de las mujeres al son de música indígena ${ }^{72}$. Es interesante la reproducción de textos de Eurípides en versión bilingüe español-mapundungún ${ }^{73}$.

En Medea del Paraná (2004), la argentina Suellen Worstell nos introduce en el mundo de los indios tobas, de la región del Chaco argentino, con una mezcla de la mitología del mundo clásico y la del de Paraná, pero concediendo gran importancia a las implicaciones políticas. Aunque Medea es nieta de Chisí, la mujer-estrella, que nos recordaría a la descendiente del Sol del texto euripideo, se ha resaltado la ausencia en la obra de Worstell del mito solar, que cede terreno a la denuncia política sobre los desmanes contra el entorno ecológico — contaminación, talas indiscriminadas-, el robo de las riquezas locales, en definitiva. Esta Medea, que causa la muerte de un Creonte dueño de un casino y de su hija, no lo hace mediante envenenamiento, sino por electrocución, al propiciar una lluvia que provoca un cortocircuito en la maquinaria eléctrica. Además, el filicidio no aparece en la obra, sino que la protagonista salta

\footnotetext{
${ }^{71}$ Cf. Zayas De Lima, Perla (2010).

72 Es fundamental el estudio de GAmBÓN, Lidia (2009): 239-249.

${ }^{73}$ Bolumburu Perl, Bernardita (2009): 381.
} 
con sus hijos sobre el río, elemento fundamental del drama. Es reseñable la presencia de de cantos en lengua indígena y el empleo de instrumentos musicales autóctonos que acercan, una vez más, fusionándolos, el elemento griego y el originario de la región.

La raza negra o mulata de las nuevas Medeas aparece, lógicamente, en aquellos dramaturgos en cuyo país es fuerte la presencia de la población de color. Así, el cubano José Triana en Medea en el espejo (1960) denuncia la exclusión de una Medea mulata, así como negra es la Medea mediante la que el brasileño Agostinho Olavo en Além do Rio (Medea) (1961) reflexiona sobre la importancia de esta raza en la configuración de su país ${ }^{74}$. En la obra de Triana nos aparece una mujer mulata, que abandonada por su marido blanco, decide envenenar a este y a su nueva esposa; pero sobre todo presenta el drama de una mujer escindida entre su identidad y su imagen — reflejada en el espejo que da título a la obra y en sus propios hijos_- una mujer abandonada y sin futuro. Son reseñables la presencia del deus ex machina y del recurso, muy propio del autor, a la mitología y folklore afrocubanos, y a algunos elementos grandilocuentes que hacen de esta obra una verdadera tragicomedia ${ }^{75}$. Agostinho Olavo en Além do Rio (Medea), centra la acción en su Brasil natal presentando una Medea, princesa africana que ha entregado por amor a su padre y a su hermano — nuevos Eetes y Apsirto - a manos de un negrero y que, traicionada por su amante que busca, como el Jasón clásico, una boda ventajosa con la hija de un capitán, envía su regalo envenenado y manda a sus hijos mestizos al río, que llevará los cadáveres ante los ojos del padre, mientras ella, como la princesa colquidea, escapa para ser libre.

En ocasiones, la marginación de las nuevas Medeas se produce por su situación social, y así pasarán por la escena iberoamericana distintas Medeas afectadas por la pobreza, la falta de vivienda, el narcotráfico, el desarraigo en la ciudad o la emigración. En los años sesenta las pasiones primitivas se trasladan, a ritmo de tango, a los suburbios bonaerenses en Medea (1967), del argentino Héctor Schujman. Una Medea madura, Joanna, expulsada de su humilde vivienda tras ser abandonada por su amante, compositor que ha logrado la fama tras años de ser mantenido por ella, aparece en Gota d'Agua (1975), de los brasileños Chico Buarque y Paulo Pontes. La obra, que recibe el nombre de la samba con la que triunfa Jasâo en el mundo de la música, conserva parcialmente los nombres míticos (Jasâo, Egeu) y supone una crítica del capitalismo hecha desde la reflexión sobre los problemas sociales de Brasil en un momento de aparente bonanza económica ${ }^{76}$.

El mundo del narcotráfico aparece en El castillo interior de Medea Camuñas (1984) ${ }^{77}$ del puertorriqueño Pedro Santaliz, que pretende dar voz a los marginados de su país, presentando una Medea vulgar, que, en lugar de maga, es vendedora de cosméticos y peluquera a domicilio. La protagonista, abandonada por un marido con problemas de drogadicción, y tras el ofrecimiento de hospitalidad de su amigo Egeo,

${ }^{74}$ Cf. Almeida Cardoso, Zelia de (2009):167-180.

75 Todo este análisis en Miranda Cancela, Elina (1999): 207-225. Cf. también CroguenneC-Massol, Gabriella (2008-2009); Morenilla Talens, Carmen (2002): 342- 367. Véase asimismo la tesis de Pérez AsEnsio, Magdalena (2009), en el capítulo «Estudio de Medea en el Espejo» y Ramos Fernández, Carolina (2009) :126-141.

${ }^{76}$ Mimoso RuIz, Duarte (2002): 1045-1058.

${ }^{77}$ Un análisis en la tesis inédita de DÁvila LóPEZ, Grace (1989): 220-233. 
trasunto dominicano del mítico rey de Atenas, morirá en una reyerta entre mafiosos. Es reseñable el tono tragicómico de la obra, a la vez que resulta interesante la utilización del elemento metaliterario, como la aseveración de seguir pautas de «don Eurípides» para la presentación del texto, y que la pervivencia de los elementos estructurales clásicos del drama, como el coro, se mezclen con la presencia de divinidades inventadas para la ocasión y con elementos del espiritismo y la santería caribeños. El tema de la emigración es el trasfondo de Medea llama por cobrar (2001) del ecuatoriano Peky Andino, quien, en una suerte de alegoría, presenta a una Medea ecuatoriana hechicera, enamorada del príncipe Jasón, representación del propio Ecuador. Esta Medea, que pretende disipar la tremenda tristeza en que Jasón está sumido, emprende un extenso periplo a la búsqueda de los vellocinos de oro, que representan a los ecuatorianos emigrantes, hijos de Jasón. Finalizado su viaje en York, el destino mayoritario de los ecuatorianitos, la Medea de Andino sufre por la traición de su amado y lo condena a la soledad y a no traer de vuelta a sus hijos ${ }^{78}$. Aunque también trata el tema de la emigración, muy distinto tono tiene la Medea (1996) del cubano Reinaldo Montero ${ }^{79}$, muy apegada al texto de Eurípides, al que da una interpretación propia, llena de un sentido del humor que desacraliza el mito clásico. Situada en Atenas y Corinto, como símbolo de un espacio atemporal, la Medea de Montero, que prescinde del filicidio, tiene un final esperanzado, con la partida de la protagonista hacia un futuro mejor donde educar a sus hijos. Finalmente, el contraste entre la vida rural y la civilización urbanita se aborda en la obra del argentino Luis María Salvaneschi Medea de Moquehua (1992). La acción se sitúa en Buenos Aires, en época contemporánea. Una Medea marginal, procedente de la localidad rural de Moquehua, con su vida reducida a un mísero cuarto de hotel, va a ser abandonada por el grosero Jasón con el que comparte su vida sin papeles, individuo que busca su boda con una bailarina, hija de Creonte, el dueño del hotel. Esta Medea, desarraigada en el mundo sórdido de la gran ciudad, matará a su rival y al padre de ella, como en Eurípides, mediante una tiara y un velo nupcial. Como contraste, el filicidio se produce mediante el prosaico recurso a un horno de gas ${ }^{80}$. Es relevante la presencia de un coro de murgueros con atuendos carnavalescos.

Son destacables las Medeas argentinas de los años 80 y 90, como la creación colectiva (de Máximo Salas, Laura Beltramo, Silvina Fernández Farrel) Medea, paisaje de hembras (1987), que se inserta dentro de la corriente que parodia los textos clásicos y cuya puesta en escena cuenta con excesos gestuales y énfasis en el primitivismo de los personajes $^{81}$; o Despojos para Medea (1992) de José Luis Valenzuela.

Otras revisiones del mito, en que se da especial importancia al elemento femenino, son la irreverente e irónica, Des-Medea $(1994)^{82}$ de la brasileña Denise Stoklos, que propone, deconstruyendo el mito griego, una Medea simbólica, que revisa la historia desde una perspectiva de género y que comparte con la de Reinaldo Montero la novedad de no cometer el filicidio, y la argentina Medea fragmentada (2006) de María

${ }^{78}$ Cf. CAMPUZANO, Luisa (2007): 405-417.

79 Cf. Miranda Cancela, Elina (2002): 317-332; Miranda Cancela, Elina (1999): 289-296; Miranda CANCELA, Elina (2005): 1105- 1124.

${ }^{80}$ Un análisis completo en CABRERo, M. ${ }^{\circ}$ del C. (2009):153-166.

${ }^{81}$ Trastoy, Beatriz (1991): 93-100, especialmente 96-97.

${ }^{82}$ StokLos, Denise (2001): 27-40. 
Barjacoba $^{83}$, en la que destaca la presencia de elementos chamánicos, y cuyo personaje busca la salvación de sus hijos. Ese mismo año se estrena la creación colectiva del Teatro La Nacional, de Chile, Little Medea (2006), recreación del mito euripideo con estética pop, en que las protagonistas son las hijas de Medea (obsérvese el cambio de sexo de la descendencia de la colquídea), y donde las historias paralelas de la madre y de las vivencias de las hijas, llevan a una incursión en el mundo de la infancia para enfatizar la soledad y la carencia de afectos de la sociedad actual y la falsedad del binomio maternidad-felicidad. Muy reciente es la obra de la uruguaya Mariana Perkovich Medea del Olimar (2009), quien localiza la acción en la región uruguaya de Olimar, en un drama unipersonal basado en el hecho real contemporáneo, rescatado de una crónica policial, de una madre que en una zona rural de Uruguay mató a su hija pequeña de seis años y en los testimonios de las reacciones con que los lectores del suceso en la prensa afrontaron la noticia. La presencia simbólica de la vaca (maternidad) con la proyección del vídeo de un matadero y de canciones del folklore regional, aparecen en una Medea, que, como la clásica, no va a recibir castigo de dioses ni de hombres. En cambio, la Medea uruguaya será condenada a la locura. El punto de partida de Perkovich, recreación del mito de Medea a partir de un crimen real, había sido adoptado ya por la escritora chilena Diamela Eltit, quien en su novela Los trabajadores de la muerte (1998), inspirada en la macabra historia leída en un periódico ${ }^{84}$, vuelve al mito de la princesa colquidea de manera confesa ${ }^{85}$ : en la obra se revisan los deseos de venganza de una madre humillada por el abandono del marido, desde el punto de vista de la identidad de género e, incluso, del psicoanálisis, para poner de relieve la violencia que sigue existiendo en el interior de la familia. En este caso, no es la mujer la que comete el filicidio, sino que es uno de sus hijos quien mata a su medio-hermana tras la consumación de un incesto, lo que nos lleva también, de alguna manera al mito de Edipo.

Finalmente, hemos de reseñar la inclusión de este mito en el teatro del absurdo por obra del dramaturgo mexicano Ignacio Arreola Haro, con su Medea (1998), que presenta unos personajes de Medea y Jasón depauperados, en una estación de metro abandonada y sucia, que no conduce a ninguna parte, $\mathrm{y}$ en el que un viejo periódico anuncia la noticia «Mujer que asesina a sus hijos y huye». El sufrimiento sin sentido y la ausencia de reflexión, propias del teatro del absurdo, marcan esta obra en la que, asimismo, se tocan los elementos heredados del drama euripideo, como la transgresión de las leyes o el deseo de venganza ${ }^{86}$.

${ }^{83}$ ZaYAs De Lima, Perla (2010). No incluimos aquí puestas en escena en Iberoamérica de obras de autores europeos, como hace Zayas en su artículo; así la Ignea Medeas, de Iannis Zambalas, llevada a la escena argentina por Juan J. Brignone, o Medea/material, de Heiner Müller, en versión de Mónica Viñao; o, incluso, la adaptación de la obra de Eurípides por la argentina Verónica Oddó, a partir de la nada fiable traducción de Germán Gómez de la Mata.

${ }^{84}$ Un estudio en WaISMAN, Sergio (2005):617-634

${ }^{85}$ Ver las entrevistas hechas a la autora por GómEz, Andrés, en el periódico La Hora del 30 de septiembre de 1998, «Diamela Eltit revive la tragedia griega» y CÁCERES, Yenny, «Medea del siglo xx», en El Mercurio 1 de octubre de 1998.

${ }^{86}$ Ideas desarrolladas en el estudio de DE BRAND, Isabel (2009):195-214. 


\subsection{Otros mitos euripideos revisitados por la literatura iberoamericana}

Al margen de las tragedias de Eurípides más recreadas en la literatura, especialmente en la dramaturgia, de Iberoamérica, como son la Medea o la Electra, hay otros mitos euripideos que esporádicamente aparecen en diversos textos literarios de los distintos países del subcontinente. Es al caso de la Alcestis, los Heráclidas, las Bacantes, Las Troyanas y, sobre todo, el Hipólito.

La Alcestis euripidea ha sido revisitada de manera satírica por el helenista y dramaturgo brasileño Jacyntho Lins Brandao en su obra Que venha a Senhora Dona (escrita en 1980 y publicada en 2007), donde el autor se adentra en el mundo de las relaciones familiares y sociales, subvirtiendo el amor conyugal y la amistad presentes en la obra griega, y presentando en escena con ironía el desamor y la falta de hospitalidad ${ }^{87}$, en el contexto del enfrentamiento del hombre con la muerte.

En 1924, el autor cubano Gustavo Sánchez Galárraga, representante de un tipo de teatro superficial, que tiene concomitancias con el que en España lleva a cabo Jacinto Benavente, escribe una de sus mejores obras, Los hijos de Heracles, inspirada en el drama homónimo de Eurípides ${ }^{88}$, sin que se sepa a ciencia cierta qué circunstancias le llevaron a retomar el tema clásico.

En 2001, Raquel Carrió y Flora Lauten estrenan en La Habana su versión desacralizadora de las Bacantes euripideas ${ }^{89}$. En estas nuevas Bacantes, Ágave se niega al destierro, subvirtiendo la función de las mujeres que, en la obra de las autoras cubanas, pasan a ser sujetos de la acción. Obra que incluye elementos anacrónicos (véase el personaje de Antínoo, amante de Adriano $^{90}$ ), y contemporáneos, en sus coros, con canciones populares del sur de Italia, en griego moderno, hace presente un tono folklórico familiar al espectador de la isla antillana. La tragedia parte del mito para subvertir, una vez más, los heredados esquemas patriarcales, y presentar una visión esperanzada en que las mujeres oponen la función de la cultura, al ansia de venganzas de Dioniso y Penteo.

Los autores cubanos exilados José Corrales y Manuel Pereiras García escriben conjuntamente la obra Las hetairas habaneras, nunca estrenada, basada en Las Troyanas de Eurípides, donde, a modo de sátira, una vez más, aparecen mezcladas las mitologías clásica y afrocubana. La respuesta alegórica ante la situación histórica de Cuba aproxima esta obra del exilio a la que se lleva a cabo en la isla durante a partir de los años sesenta ${ }^{91}$. La acción se sitúa en un burdel cubano, donde las jineteras van a ser castigadas por los dioses afrocubanos por aceptar las nuevas ideas revolucionarias, enfatizando sobremanera la importancia de la sexualidad y asignando la impotencia a la figura del tirano.

87 Freitas Moreira, Flavia (2010): 169-183.

${ }^{88}$ Rescatada por Montes Huidobro, Matías (2010).

${ }^{89}$ Estudiadas en detalle por Miranda CANCEla (2006c).

${ }^{90}$ Curiosamente, también presente de forma anacrónica en la Antígona Furiosa de Griselda Gambaro, cf. supra.

${ }^{91}$ Montes Huidobro, Matías (2004). 
Finalmente, elementos del Hipólito euripideo ${ }^{92}$ (indisociables, a mi parecer, casi siempre de los de la Fedra de Séneca) ya se recrearon en la escena en el primer tercio del siglo xx con Cuando tengas un hijo (1929), del argentino Samuel Eichelbaum, quien, según su concepción de la literatura, dota a su obra de un final conciliador y convencional. Distinto tratamiento aparece en el drama del renovador de la escena mexicana Xavier Villaurrutia, quien en su obra La Hiedra (1940 [41]) traslada también la historia mítica a época contemporánea, variando, entre otros elementos, los motivos del rechazo de Hipólito a su madrastra, que van del sentimiento de pudor religioso del texto euripideo, a un rechazo a la sustituta de la madre en el del mexicano, para teñir finalmente el drama de elementos existencialistas ${ }^{93}$. Asimismo, dentro de la dramaturgia mexicana, encontramos cincuenta años después la Fedra (1988) de Héctor Mendoza. La novedad mitográfica de la pieza es que, por el contrario a lo que la tradición trasmite, Hipólito desea físicamente a Fedra y su huida no se realiza en función de su virtud, sino del miedo que siente de la fuerza destructora que engendra la pasión desmedida de su madrastra. La obra, que habla de la fuerza de la sexualidad, superior a la del amor ${ }^{94}$, presenta la imagen impactante de una Fedra que mutila por castración el cuerpo del joven Hipólito. También dentro de la literatura mexicana encontramos la pieza dramática Fedra y otras griegas (1996), de Ximena Escalante, obra erudita, plagada de procedimientos intertextuales, hasta constituir un auténtico centón con citas de Séneca, Racine y Sor Juana Inés de la Cruz ${ }^{95}$, pero en la que el texto de Eurípides no es determinante.

Asimismo, aparecen elementos del mito de Hipólito en algunas obras de narrativa, como la novela Os Sinos da Agonia (1974), del brasileño Autran Dourado, en los cuentos Los secretos retozos de Fedra, la niña vieja (1983), del colombiano Germán Uribe y La sombra en el espejo (1986), de la costarricense Emilia Macaya ${ }^{96}$, así como en la novela del premio Nobel peruano Mario Vargas Llosa, Elogio de la madrastra (1988).

\section{A MODO DE CONCLUSIÓN}

De la revisión de este corpus, necesariamente abierto, de obras que continúan en Iberoamérica los diversos mitos que los dramaturgos griegos llevaron a la escena ateniense podemos entrever algunas tendencias generales.

a) El mito de Antígona parece ser el que con más frecuencia se retoma en la literatura Iberoamericana a partir de la segunda mitad del siglo xx. Ello viene en buena medida condicionado por la propia historia política de los diversos países, que hace que el tema del individuo que se enfrenta a la tiranía resulte

${ }^{92}$ Sobre la pervivencia de este mito es ya clásico el trabajo de LóPEz CABALLERo, Alberto (1964): 425-438.

${ }^{93}$ Granda Olmedo, Maria Nieves (1994-1995): 139-150.

${ }^{94}$ Sten, María (2003): 35-36.

${ }^{95}$ Rinaldi, Daniel (2008): 293- 321.

${ }^{96}$ Bañuls, José Vicente, CresPo, Patricia (2008): 563-589. 
especialmente atractivo. Asimismo, el asunto de la falta de enterramiento del cadáver de Polinices ha servido como metáfora para la denuncia de las víctimas desaparecidas en las distintas dictaduras latinoamericanas.

b) Muy de cerca le sigue el mito de Medea, empleado, sobre todo, para denunciar la situación de la mujer latinoamericana contemporánea, bien por su raza, o por su pobreza, o por la situación de angustia en que vive la maternidad. Es reseñable que en los últimos tiempos aparecen algunos dramas basados en noticias periodísticas que dan cuenta de filicidios reales.

c) Si muy frecuentemente los mitos sirven en la literatura iberoamericana para la denuncia de situaciones políticas o sociales indeseable, no se excluyen otros usos, como la introspección psicológica, frecuentemente desde el punto de vista psicoanalítico.

d) Tanto en el mito de Medea como en el de Antígona hay un cierto gusto por situar la acción en épocas pasadas de la historia de Iberoamérica en las que se enfrenten los blancos con los indígenas.

e) Y es que el elemento indígena se potencia con frecuencia, insertando en la obra elementos de la música o del folklore autóctono, en ocasiones, mezclado con el clásico. En este sentido es importante la presencia del elemento indígena en los lugares de la obra que corresponderían a la parte coral de la tragedia.

f) Otros mitos se han revisado en claves muy diversas dentro de la literatura iberoamericana: así, el de Prometeo ha adquirido tintes filosóficos, poéticos o de denuncia política, la figura de Ifigenia sirve tanto para hablarnos del exilio, como de la condición femenina, y la saga de los Atridas se relee tanto en clave psicoanalítica, como para hablarnos de asuntos tan diversos que van de la perversión de las relaciones familiares en Iberoamérica tradicional al perdón cristiano. Algo similar ocurre con el mito de Edipo, que sirve de instrumento para ridiculizar la figura del tirano, pero también se caricaturiza con elementos hipersexuales.

g) Es evidente, en todo caso, la tendencia a la transgresión de la solemnidad del mito clásico y a mezclar el drama con elementos satíricos en el empleo del mito en general.

h) Asimismo, se tiende a conservar sólo parcialmente los nombres de los héroes clásicos y a mezclarlos con nombres indígenas o contemporáneos, lo que se corresponde bien con la tendencia a localizar la acción en época contemporánea, o, en el caso de los mitos de Antígona y Medea, como dijimos, en época de luchas entre blancos e indios. De manera análoga, es frecuente dotar a la heroína del nombre griego seguido de un apellido local o moderno (Electra Garrigó, Antígona Vélez, Antígona Sellers, Medea Navarro) o incluso muy común (Antígona Pérez, Medea González), para aproximar e individualizar al personaje. 
Las reflexiones aquí presentadas suponen sólo un punto de partida para un estudio más detallado ${ }^{97}$ al que obliga, entre otras cosas, el hecho de que cada año surjan nuevas versiones de los trágicos griegos en Iberoamérica, hasta el punto que resulta ilusoria cualquier pretensión de exhaustividad al revisar un tema particularmente fecundo. Esta querencia por la relectura de los trágicos se debe, sin duda, a que el pueblo americano ha reunido su gusto idiosincrático por el teatro con la recuperación, a lo largo del siglo xx, de un legado clásico del que se reconoce heredero, si bien mayoritariamente se ha servido de la transgresión del mito y de la fusión del elemento helénico y los elementos americanos autóctonos, para hacer suyos los temas trágicos y poder utilizarlos desde una perspectiva poliédrica.

\section{BiBLIOGRAFÍA}

\section{Estudios}

Aguilú De Murphy, Raquel (2002), «Representación absurdista del mito clásico en "Electra Garrigó": desmitificación, humor e incomunicabilidad lingüística», Caribe: revista de cultura y literatura, $4-5, \mathrm{n}^{\circ}{ }^{\circ}$ : $80-92$.

Almeida CARdoso, Zelia de (1998-1999), «El teatro brasileño y la tradición clásica», Praesentia. Revista venezolana de Estudios Clásicos, 2-3: 15-27.

- (2009), «Reflexos das Medéias clássicas no teatro brasileiro contemporâneo», en A. Pociña y A. López (eds), En recuerdo de Beatriz Rabaza. Comedias, tragedias y leyendas grecorromanas en el teatro del siglo XX, Granada, Universidad de Granada: 167-180.

Álvarez Morán, M. ${ }^{a}$ Consuelo, e Iglesias Montiel, Rosa M. ${ }^{\text {a }}$ (1999), «Fidelidad y libertad mitográficas en Los siete contra Tebas de Antón Arrufat», en M.C. Álvarez Morán y M.R. Iglesias Montiel (eds.), Contemporaneidad de los clásicos en el umbral del tercer milenio, Actas del Congreso Internacional de Los Clásicos. La Tradición Greco-latina ante el siglo XXI (La Habana, 1 a 5 de diciembre de 1998), Murcia, Universidad de Murcia: 261-270.

Arenas Monreal, Rogelio (2004), Alfonso Reyes y los hados de febrero, UNAM-Dirección de Publicaciones-UABC.

ARencibia Rodríguez, Lourdes (1993), «Apuntes para una historia de la traducción en Cuba»; Livius 3: 1-17.

ARLT, Mirta (2000), «Ricardo Monti: hacia un teatro epifánico», en O. Pellettieri, El teatro del año 2000, Buenos Aires: 52-53.

Bailey GutiérRez, Alberto K. (2010), Franz Tamayo: Mito y Tragedia, La Paz, Plural editores. Bañuls Oller, José Vicente, y Morenilla Talens, Carmen (2008), «Antígonas», Debats, 101: 79-89.

${ }^{97}$ Actualmente formamos parte de un proyecto de investigación internacional titulado Mitos clásicos en el teatro iberoamericano actual, dirigido por la Profesora Helena Maquieira y financiado por el CEAL-Banco de Santander. 
Bañuls, José Vicente, y CRespo, Patricia (2008), «La sombra de Fedra en el espejo de Emilia Macaya (1986)», en A. Pociña, y A. López (eds.), Fedras de ayer y hoy. Teatro, poesía, narrativa y cine ante un mito clásico, Granada: 563-589.

Baptista Gumucio, Mariano (1979), Franz Tamayo. Obra escogida, Ayacucho, Caracas.

BARQuET, Jesús J. (1995), «Heteroglosia y subversión en Los siete contra Tebas de Antón Arrufat», en Matías Montes Huidobro y Yara González Montes (eds.), Anales Literarios / Dramaturgos 1, 1: 74-87.

BARQuet, Jesús J. (1999), «Subversión desde el discurso no-verbal y verbal de Los siete contra Tebas de Antón Arrufat», Latin American Theatre Review 32, 2: 19-33.

- (2000), «El caso se investiga: Antón Arrufat y Los siete contra Tebas», La Palabra y el Hombre [Xalapa, Mexico] 115: 59-69

- (2002a), «Texto y contexto en la recepción y génesis de los Siete contra Tebas», Corner, 5: 1-11. Versión electrónica: <http://www.cornermag.org/corner05/pag01.htm>

- (2002b), Teatro y revolución cubana: Subversión y utopía en Los siete contra Tebas, de Antón Arrufat. Intro. José A. Escarpanter. Lewiston, NY: Edwin Mellen.

Bernal Lavesa, Carmen (2006), «La tragedia Dido de Juan Cruz Varela», en C. Morenilla Talens, J.V. Bañuls Oller y F. de Martino, El teatro greco-latino y su recepción en la tradición occidental, Levante, Bari: 83-112.

Biasoli, Claudia María (2007), «De lo privado a lo público: Antígona, un acercamiento a la obra La cabeza en la jaula de David Cureses (1963)», ponencia en la Jornada de Debates sobre Literatura Latinoamericana y Estudios de Género, Universidad de Buenos Aires, octubre de 2007.

Biglieri, Aníbal A. (2009), «La Argentina de Antígona Vélez», en A. Pociña, A. López (eds.), En recuerdo de Beatriz Rabaza: comedias, tragedias y leyendas grecorromanas en el teatro del siglo $X X$, Granada, Universidad de Granada, 111-122

Bolumburu Perl, Bernardita (2009), «La transfiguración histórica del mito de Medea: de Eurípides a Christa Wolf», Literatura: teoría, historia y crítica, 11: 381.

BonACCORSI, Nélida Y GARrido, Margarita (1997), «Antígona en Plaza de Mayo Un diálogo entre Literatura e Historia social», Revista de Lengua y Literatura, años 9-11, n. ${ }^{\circ}$ 17-22: 143-150.

- (1999), «Antígona en Iberoamérica», en M.C. Álvarez Morán y M.R. Iglesias Montiel, Contemporaneidad de los clásicos en el umbral del tercer milenio. Actas del Congreso Internacional de Los Clásicos. La Tradición Greco-latina ante el siglo XXI (La Habana, 1 a 5 de diciembre de 1998), Murcia, Universidad de Murcia: 271-280.

Bosch, María del Carmen (1997), «Una Antígona cubana: atrás queda el polvo», anunciado para las Actas del congreso internacional de literatura iberoamericana y tradición clásica Barcelona-Valencia, 21-25 de octubre de 1997.

Bravo de Laguna Romero, Francisco J. (2010), «De la Cólquide a la Pampa: una Medea en "La Frontera" de David Cureses», Arrabal, n. ${ }^{\circ}$ 7-8 (ejemplar dedicado a: Teatro Hispanoamericano): 131-138.

Bravo De Laguna Romero, Francisco José, y Oliva Cruz, Juan Ignacio (1999), «La pervivencia de las heroínas griegas en el teatro argentino contemporáneo: una revisión del mito de Electra», Myrtia 14: 201-218.

Burguera Nadal, María Luisa (1997), «Antígona y La hojarasca: un ejemplo de imagen cultural en el texto literario», en R. Pellicer y A. Saldaña Sagredo (coord..), Quinientos años de 
soledad : actas del Congreso «Gabriel García Márquez», celebrado en la Universidad de Zaragoza del 9 al 12 de diciembre de 1992, Zaragoza, Universidad de Zaragoza: 409-416.

Cabrera Ortega, Yoandy (2010), «Tebas desde la penumbra», Cuadernos Kore, 2010. Versión electrónica: <http://kusan.uc3m.es/CIAN/index.php/CK/article/view/1046/487>

Cabrero, M. ${ }^{a}$ del Carmen (2009), «Argentinidad de Medea: de la Cólquide a Moquehua, via Coliqueo», en A. Pociña y A. López (eds.), En recuerdo de Beatriz Rabaza. Comedias, tragedias y leyendas grecorromanas en el teatro del siglo $x x$, Granada, Universidad de Granada: 153-166

Campuzano, Luisa (2002), «Electra en Quisqueya», Hispanista 96. Versión electrónica: <http:// www.hispanista.com.br/revista/artigo96esp.htm>

- (2007), «Medea en el Metro de Nueva York», en C. Morenilla Talens, J.V. Bañuls Oller y F. De Martino (eds.), El teatro grecolatino y su recepción en la tradición universal, 2 vols., Levante, Bari: 405-417.

Cantarela, Eva (2009), «Medea, víctima o asesina en serie», en El dios del Amor, México, Paidós: $39-47$.

Cañizares Ferriz, Patricia (2002), «La reescritura del mito clásico en La tierra insomne o La puta madre, del dramaturgo chileno Marco Antonio de la Parra», en A. Espigares, A. Aldama y M.F. del Barrio (coords.), Nova et vetera. Nuevos horizontes de la Filología Latina, Madrid, S.E.L.: 647-660.

CARTER, Sheila Yvonne (1980), «Ifigenia cruel: obra dramática de Alfonso Reyes», en E. Rugg y M. Alan Gordon (coords.), Actas del Sexto Congreso Internacional de Hispanistas, University of Toronto: 164-167.

Cervera, Vicente (1995), «Electra Garrigó de Virgilio Piñera. Años y leguas de un mito teatral», Cuadernos hispanoamericanos, vol. 545: 149-156.

Croce, Marcela (2000-2001), «Leopoldo Marechal: una versión suburbana de los clásicos», Inti 52-53: 203-238.

Croguennec-Massol, Gabriella (2008-2009), «Marginalisation et identité dans Medea en el Espejo de José Triana», Ateliers du Séminaire Amérique Latine de l'Université Paris-Sorbonne, $\mathrm{n}^{\circ}$ 4. Versión electrónica: <http://www.ch.lautre.net/CRIMIC/IMG/ateliers/massol. pdf $>$

DAUSTER, Frank (1985), «La generación de 1924: el dilema del realismo», Latin America Theatre Review, 18/2: 13-22.

DÁvila LóPEz, Grace (1989), Diversidad y Pluralidad en el teatro puertorriquño contemporáneo: 1965-1985. Universidad de California, Irvine.

DE BRAND, Isabel (2009), «Medea de Ignacio Arriola Haro: de la antigüedad clásica al Teatro del Absurdo latinoamericano», en David García Pérez (coord.), Teatro griego y tradición clásica, México, UNAM: 195-214.

Depretis, Giancarlo (1994), «Del Mediterráneo al Caribe: la "Electra Garrigó” de Virgilio Piñera», en J. Marco Revilla (coord.), Actas del XXIX Congreso del Instituto Internacional de Literatura Iberoamericana, Barcelona 15-19 de junio de 1992, vol. 4, Barcelona: 179-184. Dos SAntos, Edilson (2008), «O clássico na tessitura de Ṕ́lades e Orestes, de Machado de Assis: breve leitura», XI Congresso Internacional da ABRALIC. Tessituras, Interações, Convergências. 13 a 17 de julho de 2008. USP - São Paulo, Brasil. Versión electrónica: $<$ http://www.abralic.org.br/anais/cong2008/AnaisOnline/simposios/pdf/060/EDILSON_ SANTOS.pdf $>$ 
Fell, Claude (1989), José Vasconcelos. Los años del águila (1920-1925), México, UNAM: 464-465.

FeLl, Claude (1994), «Ideario literario de José Vasconcelos», NRFH 42: 549-562.

FigueroA, Ana (2001a), «Locas mujeres de Lagar II: "Electra en la niebla"», Alpha: revista de artes, letras y filosofia, 17, 2001: 51-62;

- (2001b), "Locas Mujeres de Lagar II: "Electra en la niebla"», en Escritoras hispanoamericanas: Albalucía Angel, Rosario Ferré, Ángeles Mastretta, Gabriela Mistral, Sylvia Molloy, Alejandra Pizarnik: espejos, desplazamientos, fisuras, dobles discursos, Santiago, Cuarto Propio: 59-71.

Freitas Moreira, Flavia (2010), «Leituras da morte», en M.F. Sousa e Silva; T.V.R. BARBOSA (org.), Traduçao e recriaçao, Belo Horizonte: 169-183.

GAmBÓN, Lidia (2009), «Medea mapuche o el diálogo Eurípides-Juan Radrigán», en A. Pociña, A. López (eds.), En recuerdo de Beatriz Rabaza. Comedias, tragedias y leyendas grecorromanas en el teatro del siglo Xx, Granada, Universidad de Granada: 239-249.

García Gual, Carlos (2003), «La Prometheida de Franz Tamayo», en G. Fernández Ariza, Literatura Hispanoamericana del siglo XX. Mímesis e Iconografía, Málaga, Universidad de Málaga: 147-168.

GARCíA, William (1997), «Sabotaje textual/teatral contra el modelo canónico: Antígona-Humor de Franklin Domínguez», Latin American Theatre Review: 15-29.

GArrels, Elizabeth (ed.) (2008), Teresa de la Parra. Ifigenia. Diario de una señorita que escribió porque se fastidiaba, Stockcero, Florida.

Gil Montoya, Rigoberto (2002), «Electra Garrigó: teatro de la modernidad», Ciencias Humanas, n. $^{\circ}$ 30. Versión electrónica: <http://www.utp.edu.co/>

GonZÁlez Betancur, Juan David (2010), «Antígona y el teatro latinoamericano», Calle 14, 4: 75-85. GonzÁlez de TobíA, Ana M. ${ }^{a}$ (2004), «Tradición Clásica en Iberoamérica», Boletín de la Academia Argentina de Letras, 69, n. ${ }^{\circ}$ 273-274: 87-124 y versión digital en Synthesis 12 (2005). Versión electrónica: <http://www.scielo.org.ar/scielo.php?script=sci_arttext\&pid $=$ S0328-12052005000100008>

GonzÁlez, Aníbal (2001), «Ifigenia’s Choice: Teresa de la Parra’s Demonic Option», Killer Books: Writing, Violence, and Ethics in Modern Spanish, American Narrative. Austin: U. Texas: 66-85.

Granda Olmedo, María Nieves (1994-1995), «Originalidad y mito en La Hiedra de Xavier Villaurrutia", Teatro. Revista de Estudios Teatrales, n. ${ }^{\circ}$ 6-7: 139-150.

Henríquez Ureña, Pedro (2008) (Vicente Cervera Salinas ed. y estudio preliminar), Historia cultural y literaria de la América hipánica, Madrid, Verbum.

Hernández, María A., y Battagliori, G.(1994), «Antígona Furiosa: nuevas significaciones para un mito», Conjunto/99: 90-95.

Huber, Elena (1974), «Sófocles y la Antígona Vélez de Leopoldo Marechal», Romanica 7, 149-156.

KöNIG, Irmtrud (2002), «Parodia y transculturación en Antígona Furiosa de Griselda Gambaro», Revista Chilena de Literatura 61: 5-20.

KueHne, Alice de (1975, «Marechal's Antígona: More Greek than French», Latin American Theatre Review 9: 19-27.

Lafarga, Francisco, Pegenaute, Luis (2009), Diccionario histórico de la traducción en España, Madrid, Gredos. 
López CABAllero, Alberto (1964), «El tema de Fedra en la literatura», Razón y Fe, 803: 425-438.

Luque Bedregal, Gino (2009), «La persistencia de la memoria: violencia política, memoria histórica y testimonio en Antígona de José Batanabe y el grupo Yuyachkani», que se puede consultar en la web <http://ddd.uab.cat/pub/trerecpro/2009/hdl_2072_40657/ Treball+de+recerca+-+Gino+Luque+Bedregal.pdf $>$

Matas, Julio (1989), «Vuelta a Electra Garrigó de Virgilio Piñera», Latin American Theatre Review: 73-79. Versión electrónica: <http://journals.ku.edu/index.php/latr/article/viewFile/782/757>

Mathus Torre, Carlos (1984), Un acercamiento a Ifigenia cruel de Alfonso Reyes. México, D.F. Mimoso Ruiz, Duarte (2002), «La Médée d'Euripide et Gota d'Agua de Paulo Pontes et Chico Buarque (1975)», en Aurora López y Andrés Pociña (eds.), Medeas. Versiones de un mito desde Grecia hasta hoy, Granada: 1045-1058.

Mir, Andrés (2007), «Los siete contra Tebas reloaded», en Esquife 58. Versión electrónica: http://www.esquife.cult.cu/primeraepoca/revista/58/10.htm>

Miranda Cancela, Elina (1983), «Prometeo en Julián del Casal», Erytheia: Revista de estudios bizantinos y neogriegos, 3: 15-28.

- (1990), «Electra en Piñera», Revista de Literatura Cubana, 14: 40- 53.

- (1999), «Palinodia de Medea en el teatro cubano actual», en M.C. Álvarez Morán y R.M. Iglesias Montiel (coords.), Contemporaneidad de los clásicos en el umbral del tercer milenio: actas del congreso internacional de los clásicos. La tradición grecolatina ante el siglo XXI (La Habana, 1 a 5 de diciembre de 1998): 289-296.

- (1999), «Un espejo para Medea en el teatro cubano», en K. Anderser, J. V. Bañuls y F. de Martino (eds.), El teatre clàssis al marc de la cultura grega i la seua pervivència dins la cultura occidental: II El teatre, Eina política, Levante Editori, Bari: 207-225.

- (2002), «Medea: otredad y subversión en el teatro latinoamericano», en F. de Martino, C. Morenilla (eds.), en El teatre clàssis al marc de la cultura grega i la seua pervivència dins la cultura occidental: V, El perfil de les ombres, Levante, Bari: 317-332.

- (2005), «Medea y su palinodia cubana en el teatro de Reinaldo Montero (1997)», en F. de Martino y C. Morenilla, Entre la creación y la recreación, Bari: 1105- 1124.

- (2006a), «El homenaje a Esquilo de Antón Arrufat», en Calzar el coturno americano, Ediciones Alarcos, La Habana: 107-131 = Revista Unión, 42 (2001), 7-15.

- (2006b), «Edipo bajo un sol tropical», en S. Regazzoni (coord.), Alma cubana: Transculturación, mestizaje e hibridismo: 99-110.

- (2006c), «Bacantes, la otra mirada», en Calzar el coturno americano, Ediciones Alarcos, La Habana: 187-203.

- (2006), Calzar el coturno americano, mito, tragedia griega y teatro cubano, Ediciones Alarcos, La Habana, 2006.

Modern, Rodolfo (2002), «Electra: entre Atenas y las Atenas del Plata», Boletín de la Academia Argentina de Letras, 67, n. ${ }^{\circ}$ 263-264: 113-128.

Molloy, Sylvia (1991), «Female Textual Identities: The Strategies of Self-Figuration», en S.Castro-Klarén, S.Molloy, and B.Sarlo (eds.), Women's Writing in Latin America: An Anthology. Boulder, Co. Westview Press: 107-124.

Montes Huidobro, Matías (2010), en su libro El teatro cubano durante la República. Cuba detrás del talón, Boulder, Co., Society of Spanish and Spanish-American Studies. 
Morenilla Talens, Carmen (2002), «Cuatro perfiles nuevos de Medea», en F. de Martino y C. Morenilla (eds.), El perfil de les ombres, Levante, Bari: 342- 367.

Moreno, Iani del Rosario (1997), «La recontextualización de Antígona en el teatro argentino y brasileño a partir de 1968», Latin American Theatre Review: 115-129.

Morris, Robert J. (1974), «The Theatre of Juan Ríos Rey», Latin American Theatre Review: 81-95.

Moya-RAgGio, Eliana (1998), «El sacrificio de Ifigenia: Teresa de la Parra y su visión crítica de una sociedad criolla», La Torre 5: 161-71.

Osorio, Myriam (2010), Agencia femenina, agencia narrativa. Una lectura feminista de la obra en prosa de Albalucía Ángel. Peter Lang, Bern, Berlin, Bruxelles, Frankfurt am Main, New York, Oxford, Wien.

Palacios, María Fernanda (2001), Ifigenia: Mitología de la Doncella Criolla. Caracas, Fondo Editorial Angria Ediciones.

PARDO, Karina (2004), «La reescritura de la escena trágica en Edipo Asesor de Benjamín Galemiri», Cyber Humanitatis n. ${ }^{\circ} 29$. Versión electrónica: $<$ http://doctrina.vlex.cl/vid/reescritura-gica-edipo-asesor-galemiri-56656781>

Pellarolo, Silvia (1992), «Revisando el canon/la historia oficial: Grieselda Gambaro y el heroísmo de Antígona», Gestos 7.13, 1992: 79-86.

Pepe de SuÁrez, Luz, "Variantes americanas de la trilogía esquilea», en A. Pociña y A. López (eds), En recuerdo de Beatriz Rabaza. Comedias, tragedias y leyendas grecorromanas en el teatro del siglo XX, Granada, 2009: 491-497.

Pérez Asensio, Magdalena (2009), El mito en el teatro cubano actual, tesis doctoral, Universidad de Murcia.

PÉrez Blanco, Lucrecio (1984), «Antígona Vélez. Apropiación y trueque del mensaje sofocleo», Cuandernos Americanos 43: 143-172.

PianAcCi, Rómulo (2004), «Antígona, una tragedia latinoamericana», en F. de Martino y C. Morenilla (eds.), El caliu de l'oikos, Bari, Levante Editori: 459-486.

Pianacci, Rómulo (2009), «Teatro, mujer y fronteras. Antígona; las voces que incendian el desierto, de Perla de la Mora», en A. Pociña y A. López (eds), En recuerdo de Beatriz Rabaza. Comedias, tragedias y leyendas grecorromanas en el teatro del siglo XX, Granada, Universidad de Granada: 499-507.

Pianacci, Rómulo E. (2004), «Antígona, una tragedia latinoamericana», en F. de Martino y C. Morenilla (eds.), El caliu de l'oikos, Bari, Levante Editori: 459-486.PiAnACCI, Rómulo E. (2007), Antígona, una tragedia latinoamericana, Valencia, ed. Gestos.

PINKLER, Leandro (2002), «La Antígona de Huertas: tragedia y tango», en J. Huertas, Antígonas: linaje de hembras, Buenos Aires, Biblos: 9-14.

PociÑA, Andrés (2005), «Una Medea argentina: La Frontera, de David Cureses», en F. de Martino y C. Morenilla, Entre la creación y la recreación, Bari: 457-479

Quintanilla, Susana (2002), «Dioniso en México o cómo leyeron nuestros clásicos a los clásicos griegos», Historia mexicana, 51, 3: 619-663.

Ragué, M. ${ }^{a}$ José (1991), «La Antígona Furiosa de Griselda Gambaro», Art Teatral, año III, n. ${ }^{\circ}$ 3: 93-95.

Ramos Fernández, Carolina (2009), «Redescubriendo los mitos griegos desde el continente americano: la Medea mulata de José Triana», Iberoamerica Global, vol. 2, n. ${ }^{\circ} 1,126-141$.

- (2004), «Electra Garrigó: El compromiso en el teatro contemporáneo», en A. Pérez Jiménez, C. Alcalde Martín y R. Caballero Sánchez (eds.), Sófocles el hombre, Sófocles el poeta. 
Actas del congreso internacional con motivo del XXV centenario del nacimiento de Sófocles (celebrado en Málaga, 29-31 de mayo de 2003), Madrid, Ediciones Clásicas: 471-477. ReYEs, Alfonso, Apuntes para la teoría literaria, en Obras Completas, XV, FCE, México, 1981. Rinaldi, Daniel (2008), «Procedimientos intertextuales en Fedra y otras griegas, de Ximena Escalante», Nova Tellus, 26, 2: 293- 321.

Ruiz PÉrEz, Ángel (1999), «Adán y Antígona de L. Marechal: héroes clásicos y argentinos», en J.V. Bañuls Oller, J. Sánchez Méndez y J. Sanmartín Sáez (eds.), Literatura iberoamericana y tradición clásica, Valencia, UAB y UV: 393-397

SeVILla Listerri, Javier (2006), «Dos Antígonas periféricas», Extravio: revista electrónica de literatura comparada, n. ${ }^{\circ}$. Versión electrónica: <http://www.uv.es/extravio/PDFs/g_sevilla.pdf $>$

SteInER, George (1987), Antígonas. La travesía de un mito occidental por la historia de Occidente, Gedisa, Barcelona.

Sten, María (2003), Cuando Orestes muere en Veracruz, México D.F., UNAM.

Stoklos, Denise (2001), «Des-Medea», Conjunto, 121: 27-40.

Teja, Ada María (2004), «Ifigenia Cruel de Alfonso Reyes, el poder femenino de romper el círculo de la violencia», Revista del CESLA 6: 237-273.

Trastoy, Beatriz (1991), «En torno a la renovación teatral argentina de los años '80», Latin American Theatre Review: 93-100

Vilanova, Ángel (1996), «Aproximaciones al estudio de Antígona Vélez, de Leopoldo Marechal, y Antígona furiosa, de Griselda Gambaro», Praesentia, Revista Venezolana de Estudios Clásicos, 1: 395-403.

- (1998-1999) «La tradición clásica grecolatina y las literaturas venezolana y colombiana de la primera mitad del siglo XIX», Praesentia 2-3. Versión electrónica: <http://interclassica.um.es/index.php/interclassica/investigacion/hemeroteca/p/praesentia/numero_2_3_1998_99>

- (1998-1999) «La tradición clásica grecolatina y las literaturas venezolana y colombiana de la primera mitad del siglo XIX», Praesentia 2-3. Versión electrónica: $<$ http://interclassica.um.es/index.php/interclassica/investigacion/hemeroteca/p/praesentia/numero_2_3_1998_99>

- (1999), «Antígona en el teatro latinoamericano: nuevas aproximaciones al análisis de Antígona Vélez de Leopoldo Marechal (1951); Pedreira das almas, de Jorge Andrade (1958); La pasión según Antígona Pérez, de Luis Rafael Sánchez (1968), y Antígona furiosa, de Griselda Gambaro (1986)», Nueva Revista de Filología Hispánica, 47, 1: 1999

- (1999), «Las heroínas del drama clásico grecolatino en el teatro iberoamericano: algunas reflexiones sobre la tragedia Argia, de Juan Cruz Varela», en J.V. Bañuls Oller, J. Sánchez Méndez y J. Sanmartin Sáez (eds.), Literatura iberoamericana y tradición clásica. Valencia, Universitat Autonoma de Barcelona.

- (1999), «Nuevas aproximaciones a las Antígonas iberoamericanas», Nueva revista de filología hispánica, 47, 1: 137-150.

- (2006), «La tradición clásica y el teatro rioplatense de las primeras décadas del siglo XIx: la obra de Juan Cruz Varela», Praesentia 7. Versión electrónica: <http://vereda.saber.ula.ve/ sol/praesentia7/angel.htm> 
Waisman, Sergio (2005), «Medea entre la taberna y el mercado: la desfiguración de la madre en "Los trabajadores de la muerte"», La Torre: Revista de la Universidad de Puerto Rico, vol. 10, n. ${ }^{\circ} 38$ : 617-634.

Zayas De Lima, Perla (2010), «Mitos griegos en el discurso teatral argentino», Telón de Fondo, Revista de Teoría y Crítica Teatral, n. ${ }^{\circ} 11$, julio de 2010. Versión electrónica: $<$ http://www. telondefondo.org $>$

ZeCchin de FASANo, Graciela (2009), «El mito de Antígona en la obra de Griselda Gambaro», en A. Pociña y A. López (eds.), En recuerdo de Beatriz Rabaza. Comedias, tragedias y leyendas grecorromanas en el teatro del siglo Xx, Granada, Universidad de Granada: 703-709.

\section{Obras colectivas fundamentales}

De Martino, Francesco, Morenilla, Carmen (2002), El teatre clàssis al marc de la cultura grega i la seua pervivència dins la cultura occidental: V, El perfil de les ombres, Levante, Bari.

- (2004), El caliu de l'oikos, Levante Editori.

- (2005), Entre la creación y la recreación, Bari,

López, Aurora y Pociña, Andrés (2002), Medeas. Versiones de un mito desde. Grecia hasta hoy, Editorial Universidad de Granada, Granada,

- (2007), Otras Medeas: nuevas aportaciones al estudio literario de Medea, Editorial Universidad de Granada, Granada.

- (2008), Fedras de ayer y de hoy. Teatro, poesía, narrativa y cine ante un mito clásico, Granada, Universidad de Granada.

Morenilla, Carmen, De Martino, Francesco, Bañuls, J.V. (2001), Fil d'Ariadna : El teatre clàssic al marc de la cultura grega i la seua pervivència dins la cultura occidental. 4[sic], Universitat de València, 3-5 de maig 2000, Levante Editori;

- (2001), Fil d'Ariadna: El teatre clàssic al marc de la cultura grega i la seua pervivència dins la cultura occidental. 4[sic], Universitat de València, 3-5 de maig 2000, Levante Editori.

- (2006), El teatro greco-latino y su recepción en la tradición occidental, Levante Editori.

Pociña, Andrés, LóPez, Aurora (2009), En recuerdo de Beatriz Rabaza. Comedias, tragedias y leyendas grecorromanas en el teatro del siglo $x x$, Granada, Universidad de Granada. 